\title{
Supramolecular Approach in Energy Conversion Devices
}

\author{
Ronaldo C. Amaral, ${ }^{\oplus a, b}$ Kassio P. S. Zanoni, ${ }^{\oplus a, c}$ Lais S. Matos ${ }^{\circledR a}$ and \\ Neyde Y. Murakami Iha ${ }^{\circledR} * a$ \\ ${ }^{a}$ Laboratório de Fotoquímica e Conversão de Energia (LFCE), \\ Departamento de Química Fundamental, Instituto de Química (IQ), \\ Universidade de São Paulo (USP), Av. Prof. Lineu Prestes, 748, 05508-000 São Paulo-SP, Brazil \\ ${ }^{b}$ Instituto Federal de Educação, Ciência e Tecnologia de São Paulo (IFSP), Campus Sorocaba, \\ R. Maria Cinto de Biaggi, 130, 18095-410 Sorocaba-SP, Brazil \\ 'Instituto de Ciencia Molecular, Universidad de Valencia, C/ Catedrático J. Beltrán, 2, \\ 46980 Paterna, Valencia, Spain
}

\begin{abstract}
This review summarizes investigations carried out at the Laboratory of Photochemistry and Energy Conversion (LFCE) in the University of São Paulo dealing with design and characterization of ruthenium(II), rhenium(I) and iridium(III) polypyridine complexes with desired photochemical and photophysical properties in light of the development of optoelectronics and photoinduced energy conversion systems. First, the breakthroughs on molecular engineering of emissive $\operatorname{Re}^{\mathrm{I}}$, $\mathrm{Ru}^{\mathrm{II}}$ and $\mathrm{Ir}^{\mathrm{III}}$ complexes for the development of highly efficient light-emitting devices, such as organic light-emitting diodes (OLEDs) and light-emitting electrochemical cells (LECs), are presented. Then, the photochemical and photophysical properties of $f a c-\left[\operatorname{Re}(\mathrm{CO})_{3}(\mathrm{NN})(\text { trans }-\mathrm{L})\right]^{+}$ complexes ( $\mathrm{NN}=$ bidentate polypyridyl ligands and trans $-\mathrm{L}=$ stilbene-like ligand), which find use in molecular machines and photosensors, are discussed. Finally, dye-sensitized energy conversion devices based on $\mathrm{Ru}^{\mathrm{II}}$ complexes and natural dyes, such as dye-sensitized solar cells (DSCs) and dye-sensitized photoelectrosynthesis cells (DSPECs), are reviewed, highlighting some strategies for photoanode engineering aiming at improved device efficiencies.
\end{abstract}

Keywords: supramolecular chemistry, energy conversion, molecular devices, solar fuels, dye-sensitized solar cells, OLEDs/LECs

\section{Introduction}

A supramolecular approach gives rise to the design of organized systems and can be conveniently exploited through metal complexes for the control of photoproperties and development of molecular devices through structurally organized and functionally integrated chemical systems. ${ }^{1-5}$ One of the strategies is the use of coordination compounds with proper ligands to pursue a high chemical stability and intense absorption in the visible ${ }^{6,7}$ with suitable redox properties for energy and/or electron transfer processes. ${ }^{8-12}$

The Laboratory of Photochemistry and Energy Conversion (LFCE) at Chemistry Institute of the University of São Paulo has been carrying out investigations in photochemistry and photophysics of coordination

*e-mail: neydeiha@iq.usp.br

Dedicated to Prof Henrique Eisi Toma on the occasion of his $70^{\text {th }}$ birthday. compounds and supramolecular systems toward molecular design and devices fabrication.

The initial studies were focused on kinetics, electrochemistry and spectroscopy of cyanoferrate(II) complexes, ${ }^{13-17}$ with emphasis on the reactivity of the ground state. The extensive investigation on kinetics and mechanisms of formation and substitution of pentacyanoferrate(II) complexes, $\left[\mathrm{Fe}(\mathrm{CN})_{5} \mathrm{~L}\right]^{3-}(\mathrm{L}=$ monodentate neutral ligand, such as $\mathrm{NO}$ or $\mathrm{CO}),{ }^{13,18,19}$ was then extended to the reactivity of coordinated NO to the cyanoferrate moiety. ${ }^{14,19}$ These studies and the solid knowledge in the ground state spectroscopy, electrochemistry and reactivity of coordination compounds complexes were proven to be fundamental for exploitation of more complex chemical systems and application in several new areas. Subsequent investigation on the photoreactivity of these compounds came as a natural step. The photosubstitution of the L ligand in $\left[\mathrm{Fe}(\mathrm{CN})_{5} \mathrm{~L}\right]^{3-}$ was first investigated in 
the early $80 \mathrm{~s} .{ }^{18,20-24}$ The data for substitutionally inert $\left[\mathrm{Fe}(\mathrm{CN})_{5} \mathrm{~L}\right]^{3-}$ with $\mathrm{L}=\mathrm{CO}, \mathrm{AsPh}_{3}$ (triphenylarsine), $\mathrm{SbPh}_{3}$ (triphenylantimony(III)), $\mathrm{P}\left(\mathrm{OCH}_{3}\right)_{3}$ (trimethyl phosphite), $\mathrm{PPh}_{3}$ (triphenylphosphine) and en (ethylenediamine) are shown in Table 1.

Table 1. Quantum yields for the photosubstitution of $\mathrm{L}$ in $\left[\mathrm{Fe}(\mathrm{CN})_{5} \mathrm{~L}\right]^{3-}$

\begin{tabular}{lccc}
\hline Complex & $\lambda_{\text {irradiation }} / \mathrm{nm}$ & $\Phi$ & Reference \\
\hline$\left[\mathrm{Fe}(\mathrm{CN})_{5} \mathrm{CO}\right]^{3-}$ & 366 & 0.9 & 20 \\
{$\left[\mathrm{Fe}(\mathrm{CN})_{5}\left(\mathrm{AsPh}_{3}\right)\right]^{3-}$} & 366 & 0.37 & 22,23 \\
{$\left[\mathrm{Fe}(\mathrm{CN})_{5}\left(\mathrm{SbPh}_{3}\right)\right]^{3-}$} & 366 & 0.15 & 22 \\
{$\left[\mathrm{Fe}(\mathrm{CN})_{5}\left(\mathrm{P}^{-}(\mathrm{OMe})_{3}\right)\right]^{3-}$} & 366 & 0.12 & 22 \\
& 366 & 0.14 & 22 \\
{$\left[\mathrm{Fe}(\mathrm{CN})_{5}\left(\mathrm{PPh}_{3}\right)\right]^{3-}$} & 336 & 0.14 & \\
& 404 & 0.15 & 22 \\
{$\left[\mathrm{Fe}(\mathrm{CN})_{5}(\mathrm{en})\right]^{3-}$} & 366 & 0.12 & \\
\hline
\end{tabular}

$\lambda_{\text {irradiation }}$ : irradiation wavelength; $\Phi$ : photochemical quantum yield; $\mathrm{AsPh}_{3}$ : triphenylarsine; $\mathrm{SbPh}_{3}$ : triphenylantimony(III); $\mathrm{P}(\mathrm{OMe})_{3}$ : trimethyl phosphite; $\mathrm{PPh}_{3}$ : triphenylphosphine; en: ethylenediamine.

The photochemistry of aqueous solutions of $\left[\mathrm{Fe}(\mathrm{CN})_{5}(\mathrm{en})\right]^{3-}$ in the presence of a large excess of the diamine ligand under continuous photolysis was the first example reported in the literature, ${ }^{20}$ having a cyanide photolabilization as the reactive deactivation pathway. The neighboring effect in the excited state was exploited as a strategy by using the ability of the dangling free amino group to capture a lower coordinate intermediate to undergo subsequent ring closure after labilization of the $\mathrm{Fe}-\mathrm{CN}$ bond, Figure $1 .^{20}$

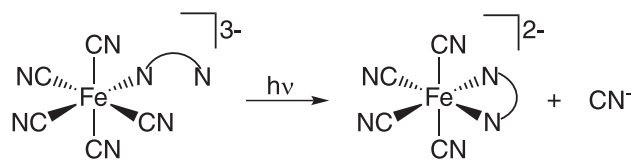

Figure 1. Neighboring effect and subsequent ring closure.

The inertness of the photoproduct, $\left[\mathrm{Fe}(\mathrm{CN})_{4}(\mathrm{NN})\right]^{2-}$, after chelating enabled its further isolation and quantitative analysis. ${ }^{25,26}$ The polarity and viscosity of the solvent have a key role on the quantum yields for the $\mathrm{CN}^{-}$release in $\left[\mathrm{Fe}(\mathrm{CN})_{5}(\mathrm{NN})\right]^{3-}$ complexes..$^{27,28}$ While the wavelength dependence accounts for different efficiencies of primary radical formation in the initial step before deactivation occurs, the dependence on medium parameters is related to the dynamics of deactivation for the formation of the final photoproduct. The medium characteristics can shift the balance from one pathway to another, tuning the efficiency of the photochemical process.

Gradually, the focus has been directed on understanding the photophysical and photochemical properties of $\mathrm{Re}^{\mathrm{I}}, \mathrm{Ru}^{\mathrm{II}}$ and IrII complexes as well as the development of photoinduced energy conversion devices, such as dye-sensitized solar cells (DSCs), dye-sensitized photoelectrosynthesis cells (DSPECs), organic light-emitting diodes (OLEDs), light-emitting electrochemical cells (LECs), molecular machines and photosensors, many of them through fruitful collaboration with Prof Carlo A. Bignozzi and Prof Thomas J. Meyer, along with highly motivated students to face such an interdisciplinary area.

In the following sections, we show that these compounds are strategical for the development of such supramolecular devices as they can exhibit a high chemical stability and intense absorption in the visible due to metal-to-ligand charge transfer ( ${ }^{1}$ MLCT) transitions, ${ }^{67}$ with suitable redox properties for energy and/or electron transfer processes. ${ }^{8-12}$ Some of these complexes also exhibit intense luminescence at room temperature, usually ascribed to a phosphorescence from the ${ }^{3} \mathrm{MLCT}$ counterpart arisen from a high spin-orbit coupling (SOC). ${ }^{29-31}$

\section{Light-Emitting Devices}

Sustainable development demands to reduce energy consumption by developing modern optoelectronics and efficient light-emitting devices. In this context, lightemitting diodes (LEDs) are alternatives for replacing old lighting technologies for their less power consumption, ${ }^{32,33}$ low voltage and current operation, ${ }^{33}$ fast response time, ${ }^{33}$ long durability, ${ }^{33,34}$ high performance, ${ }^{35}$ low maintenance ${ }^{34}$ and eco-friendly fabrication processes. ${ }^{33,35}$

A LED is based on inorganic semiconductors such as $\mathrm{GaN}$ and GaAs. However, crystals usually need to be highly pure to ensure high performances in most optoelectronic applications. ${ }^{36}$ On the other hand, OLEDs are characterized by more facile processing, although they lack the long-term chemical and thermal stability usually observed for inorganic ones. ${ }^{37}$

An OLED is assembled in a supramolecular multilayer configuration of organic semiconductors with an active emissive film positioned in between $\mathrm{p}$ - and n-type charge transport layers (hole transport layer (HTL) and electron transfer layer (ETL)). Detailed mechanisms for the OLED's operating principle has been reviewed extensively elsewhere ${ }^{38-40}$ and Figure 2 shows a simplified view. When an external voltage is applied between the electrodes, holes are injected through the anode and electrons are injected through the cathode. ${ }^{41}$ The holes/ electrons are transported through HTL/ETL to reach the active emissive layer and fill its highest occupied molecular orbital (HOMO)/lowest unoccupied molecular orbital (LUMO), respectively. ${ }^{40,41}$ Within the emissive layer, electrons and holes reach a recombination zone, 
where both particles form a bound state called exciton. Excitons populate the lowest-lying excited state, from which a luminescent decay occurs, resulting in the emission of light from the device. ${ }^{42}$

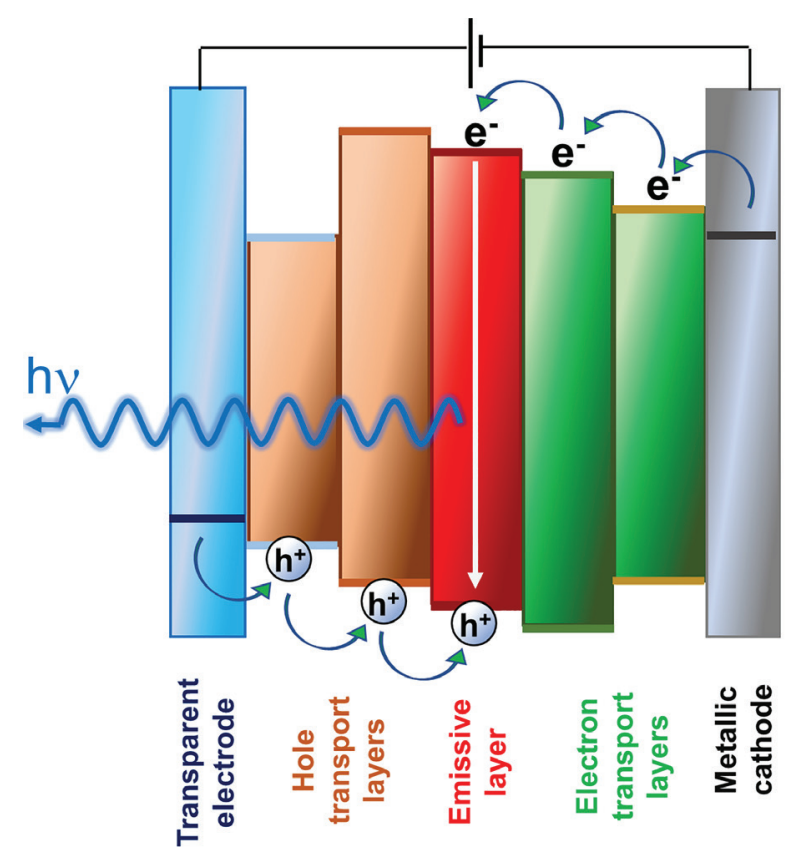

Figure 2. The multilayered architecture, the usual components and the operating mechanism of an OLED (simplified; more details in the main text).

Doping the organic emissive layer with a phosphorescent guest molecule (such as heavy-metal $\mathrm{d}^{6}$ coordination compounds) has been a successful strategy for increasing luminous efficiencies and controlling the emitted color, standing as the second generation of OLEDs..$^{38,39,42-44}$ Under operation, excitons are generated in the organic layer, then posteriorly transferred to the guest complex excited state, from which a phosphorescent deactivation occurs.

Conversion of electricity into light can be also reached using LECs in a simpler architecture. These devices share a similar base structure with OLEDs, in which an emissive film is placed in between a metallic and a transparent electrode; however an active layer in LECs contains mobile ions, changing the operating mechanism and properties of the device. ${ }^{45-50}$ As summarized in Figure 3, application of bias causes the mobile charge carriers to drift within the active film towards the proper electrode with an opposite charge..$^{51,52}$ The ion redistribution leads to a formation of double layers close to the electrodes. The double layers facilitate injection of electrons and holes into the emissive film when the applied bias is enough to overcome the HOMO-LUMO gap (or bandgap in the case of a semiconductor) of most usual emitters. ${ }^{44}$ After injection, electrons and holes produce excitons which then recombine resulting in luminescence. ${ }^{52}$

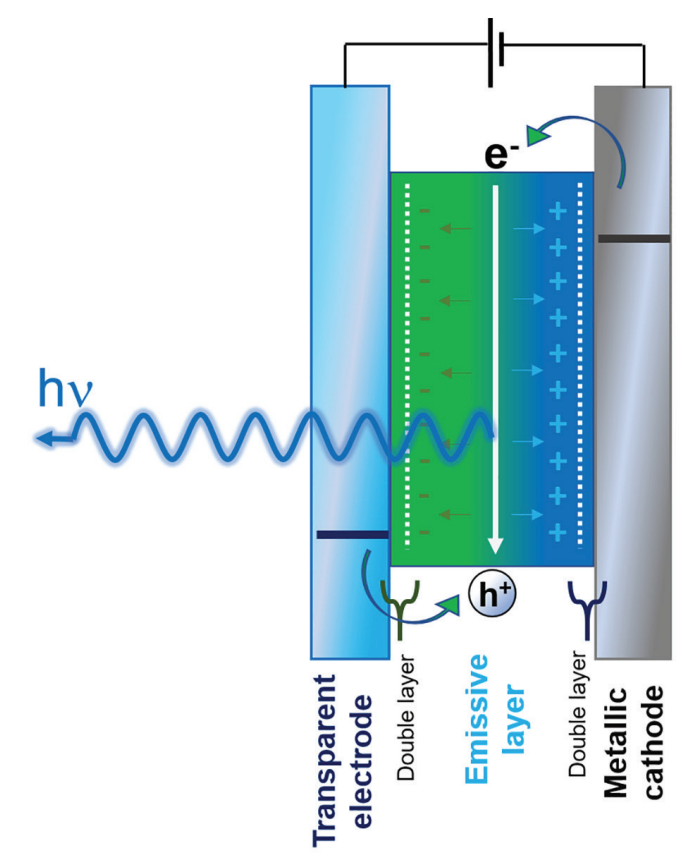

Figure 3. The sandwich type architecture, the usual components and the operating mechanism of a LEC (simplified; more details in the main text).

Usually, efficient green- and red-light emission can be reached with these devices; even though obtaining suitable blue-light systems remains a challenge. The LFCE has been investigating numerous phosphorescent coordination compounds, mostly of $\mathrm{Ru}^{\mathrm{II}}, \mathrm{Re}^{\mathrm{I}}$ and $\mathrm{Ir}^{\mathrm{III}}$ for applications in light-emitting devices with focus on molecular engineered control of their color and emission quantum yields along with thorough photophysical elucidation.

\subsection{Ruthenium(II) complexes}

The emission of $\left[\mathrm{Ru}(\mathrm{NN})_{3}\right]^{2+}$ complexes $(\mathrm{NN}=$ bidentate polypyridinic ligands, such as 2,2'-bipyridine (bpy), 1,10-phenanthroline (phen) and their derivatives) has been extensively investigated over the past 70 years with detailed photophysical elucidation discussed elsewhere and reviewed in several publications. ${ }^{53-58} \mathrm{The}^{3} \mathrm{MLCT}_{\mathrm{Ru} \rightarrow \mathrm{NN}}$ state of $\left[\mathrm{Ru}(\mathrm{NN})_{3}\right]^{2+}$ complexes is a strong oxidizing and a reducing agent ${ }^{59}$ and its phosphorescent deactivation to the singlet ground state occurs at room temperature in microseconds, with a broad non-structured spectrum and emission quantum yields from 10 to $0.1 \%{ }^{39}$ and usually in the orange-red spectral region. ${ }^{60}$

Our initial investigation on light-emitting devices with ruthenium(II) polypyridinic complexes, Figure 4, to build single-layer LECs, Figure 5, by spin coating on indium tin oxide (ITO) substrate, had the ITO/Ru-1:PMMA/Al architecture (PMMA: poly(methyl methacrylate)).

Both the electroluminescence and photoluminescence spectra (and CIE coordinates) of Ru-1 and Ru-2 are similar 

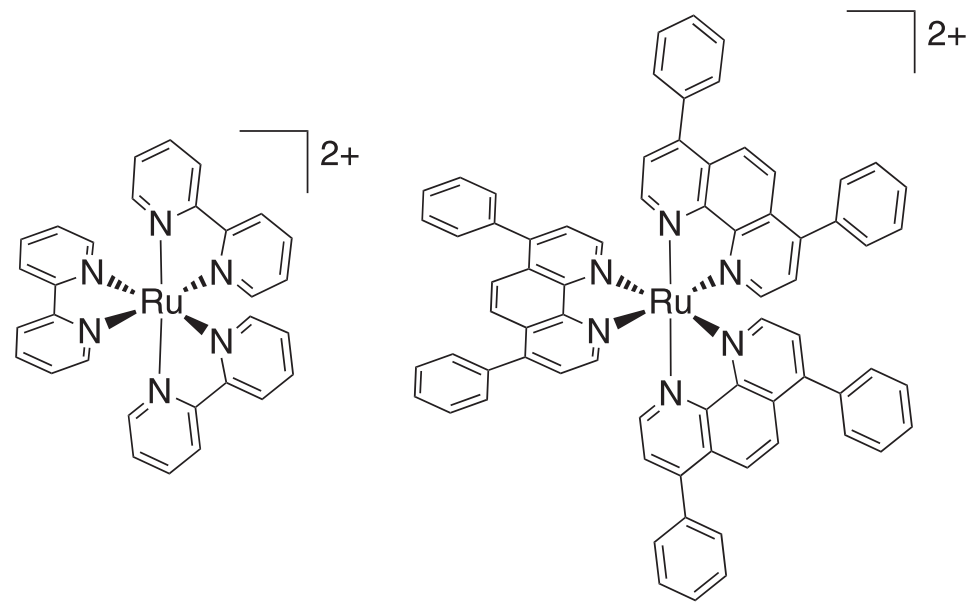

Ru-1

Ru-2

Figure 4. Ruthenium(II) complexes investigated by LFCE for light-emitting devices.
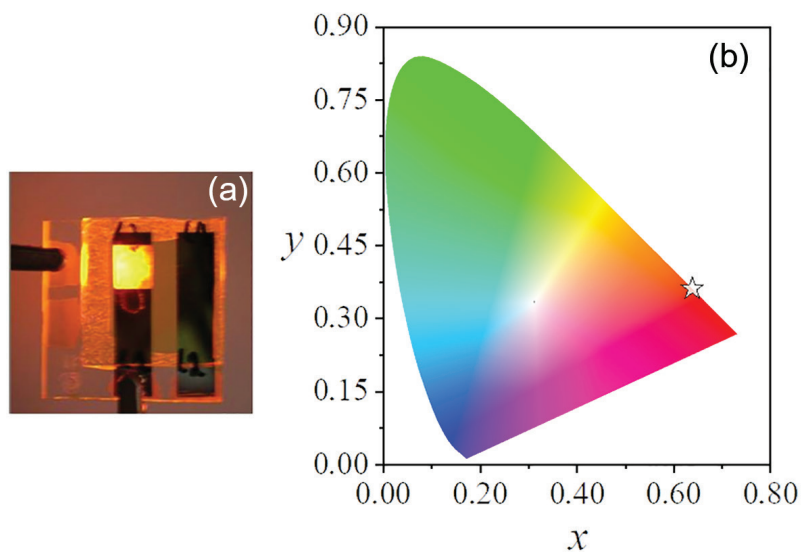

Figure 5. (a) ITO/Ru-1:PMMA/Al LEC under operation, emitting orange light with CIE color coordinate indicated in diagram (b).

(with maximum ca. $630 \mathrm{~nm}$ ). The Comission Internationale d'Eclairage (CIE) quantified the color perceived by humans in three matching functions or spectral sensitivity curves $(\overline{\mathrm{x}}(\lambda), \bar{y}(\lambda)$ and $\bar{z}(\lambda))$ based on trichromatic stimuli of the human virtual cortex (for more details, see literature). ${ }^{44}$ Their CIE coordinates $(x, y)$ is $(0.64,0.36)$. The best device efficiency was obtained for the Ru- 1 device with ca. $10 \mu \mathrm{W}$ optical output power at the band maximum with a wall-plug efficiency higher than $0.03 \% .{ }^{61,62}$

\subsection{Rhenium(I) complexes}

Tricarbonyl polypyridinic rhenium(I) complexes can find a great variety of applications in biological sensors, ${ }^{63-69}$ photocatalysis of $\mathrm{CO}_{2}$ to $\mathrm{CO},{ }^{70,71}$ photosensitization of ${ }^{1} \mathrm{O}_{2},{ }^{72,73}$ polymer sensors ${ }^{74}$ and light-emitting devices. ${ }^{75-77}$

Lifetimes as high as ten microseconds are observed in $f a c-\left[\operatorname{Re}(\mathrm{CO})_{3}(\mathrm{NN})(\mathrm{L})\right]^{0 /+}$ complexes $(\mathrm{NN}=$ bidentate polypyridinic ligands and $\mathrm{L}=$ halogenates, phosphines and pyridine derivates), ${ }^{74,78-80}$ due to the strong spin-orbit coupling (SOC) exerted by the $\mathrm{Re}^{\mathrm{I}}$ metal center (with an estimated SOC constant $\xi_{\mathrm{Re}}$ between 700 and $\left.900 \mathrm{~cm}^{-1}\right)^{81}$ facilitating an efficient population of the emissive ${ }^{3} \mathrm{MLCT}_{\mathrm{Re} \rightarrow \mathrm{NN}}$ excited state. The strong $\pi$ back-bonding between the carbonyl ligands and the metal center usually leads to a restricted-energy gap between $\mathrm{Re}^{\mathrm{I}} \mathrm{d}$ orbitals and $\pi^{*}$ ligand orbitals involved in the MLCT transition, therefore emission wavelengths lie predominantly in the green-yellow to orange-red spectral region. ${ }^{60}$

The LFCE investigated photophysical behaviors of $f a c-\left[\operatorname{Re}(\mathrm{CO})_{3}(\mathrm{NN})(\mathrm{L})\right]^{0 /+}$ complexes, Figure 6 , and application in OLEDs. ${ }^{77,82,83}$ The emission of these complexes is ascribed to ${ }^{3} \mathrm{MLCT}_{\mathrm{Re} \rightarrow \mathrm{NN}}\left({ }^{3} \mathrm{MLCT}_{\mathrm{Re} \rightarrow \text { bpy }}{ }^{3} \mathrm{MLCT}_{\mathrm{Re} \rightarrow \text { quin }}\right.$ and ${ }^{3} \mathrm{MLCT}_{\mathrm{Re} \rightarrow \text { isoquin }}$ for Re-1, Re-2 and Re-3, respectively) with

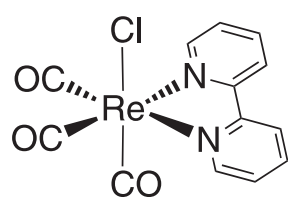

Re-1

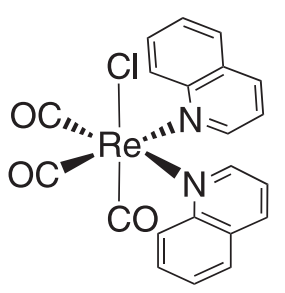

Re-2

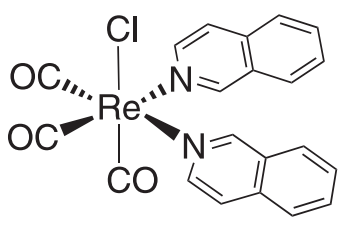

Re-3

Figure 6. Luminescent rhenium(I) complexes investigated by the LFCE for light-emitting devices. 
strong rigidochromic effects, highly sensitive to the media rigidity, as exemplified in Figure 7 for Re-1..$^{83,84}$

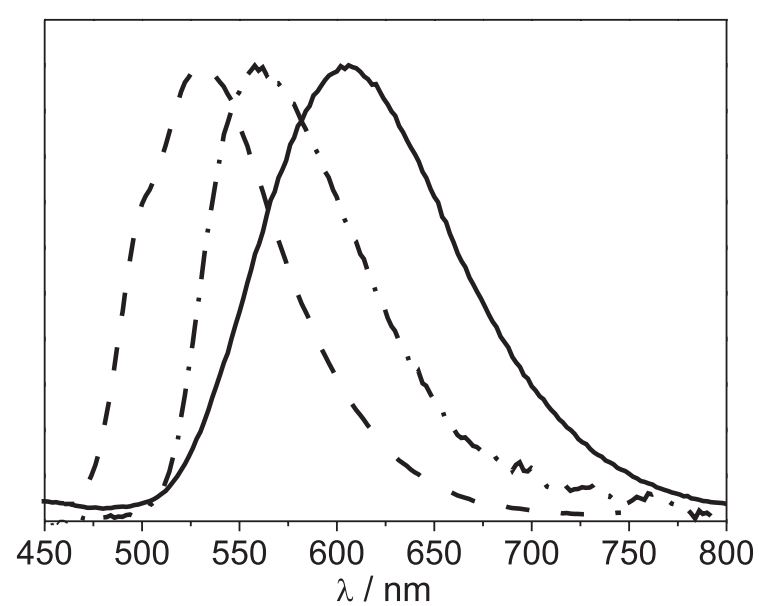

Figure 7. Emission spectra for Re-1 in fluid acetonitrile at $298 \mathrm{~K}(-)$, in rigid PMMA (poly(methyl methacrylate)) at $298 \mathrm{~K}(-\bullet-\bullet-)$ and in rigid EPA (5:5:2 diethylether:isopentane:ethanol) at $77 \mathrm{~K}(---)$, with $\lambda_{\text {excitation }}=300 \mathrm{~nm}$.

The electroluminescence spectrum of OLED using Re-1 as a dopant in a thin film of polyvinylcarbazole (PVK), an organic semiconductor, ${ }^{83}$ is ascribed solely to the very intense ${ }^{3} \mathrm{MLCT}$ emission of the guest complex at $580 \mathrm{~nm}$, due to an efficient energy transfer from the host to the dopant. ${ }^{77,83}$ The electroluminescence spectrum of spin-coated films of PVK without Re-1 complex in the ITO/PEDOT:PSS/PVK/butylPBD/AI OLED (PEDOT: poly(3,4-ethylenedioxythiophene), PSS: poly(styrenesulfonate), butyl-PBD: 2-(4-biphenylyl)5-(4-tert-butylphenyl)-1,3,4-oxadiazole, Al: aluminum) exhibits a characteristic blue emission, $\lambda_{\max }=420 \mathrm{~nm}$, assigned to the PVK excimer (CIE coordinates: 0.19, 0.12), Figure 8a, while ITO/PEDOT:PSS/PVK:Re-1/butylPBD/Al architecture device, resulted in an eye-observed apparent white emitter device (CIE coordinates: $0.42,0.45$ ), Figure 8 b.

\subsection{Iridium(III) complexes}

The $m e r-\left[\operatorname{Ir}(\mathrm{NC})_{2}(\mathrm{LX})\right]^{+}$complexes $(\mathrm{NC}=2$-phenylpyridine or similar bidentate ligands, organometallated to $\mathrm{II}^{\mathrm{III}}$ through $\mathrm{NC}$ in a 5-membered metallacycle, and $\mathrm{LX}=$ diimines, picolinates, acetylacetonates or similar bidentate ligands) usually present excellent thermal and photochemical stabilities with a variety of ligands and find applications in biological phosphorescent labels and sensors, ${ }^{85,86}$ photodynamic therapy, ${ }^{87,88}$ metallopharmaceuticals with antitumoral activities, ${ }^{89,90}$ dye-sensitized solar cells ${ }^{91,92}$ and catalysis. ${ }^{93,94}$

These complexes exhibit microsecond-lived excited states with impressive emission quantum yields (close to $100 \%$ ) as a consequence of iridium's very-strong SOC
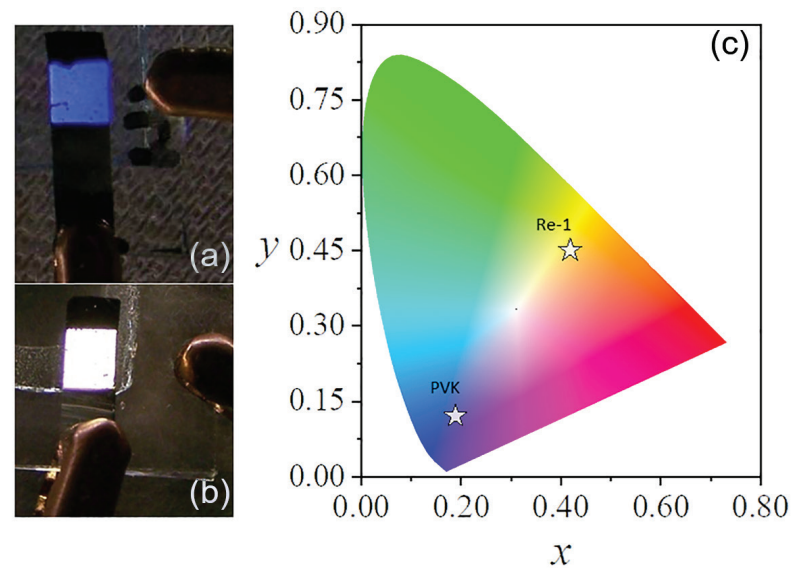

Figure 8. (a) ITO/PEDOT:PSS/PVK/butyl-PBD/Al and (b) ITO/ PEDOT:PSS/PVK:Re-1/butyl-PBD/Al OLEDs under operation, with their CIE color coordinates indicated in diagram (c).

(with estimated SOC constant $\xi_{\text {Ir }}$ around $4430 \mathrm{~cm}^{-1}$ )..$^{95}$ They also undergo color and efficiency tuning through judicious molecular engineering by controlled changes in the ligands, allowing emission in all three primary colors-blue, green and red. ${ }^{44,96,97}$

$m e r-\left[\operatorname{Ir}(\mathrm{NC})_{2}(\mathrm{LX})\right]^{+}$complexes present overlapped excited states in the visible with strong SOC-induced mixing of electronic characters, leading to hybrid excited states (see more information in the literature).$^{44}$ The weak lowest-energy band in most mer- $\left[\operatorname{Ir}(\mathrm{NC})_{2}(\mathrm{LX})\right]^{+}$complexes is ascribed to a SOC-induced direct absorption to the normally spin-forbidden lowest-lying triplet excited state, $\mathrm{T}_{1} \cdot{ }^{38}$ After excitation at any wavelength, SOC facilitates rapid population of $\mathrm{T}_{1}$ via a series of intersystem crossings and internal conversions and deactivation from $\mathrm{T}_{1}$ usually occurs through intense phosphorescence. ${ }^{98}$

The emission color can be judiciously tuned by addition of electron-donating or -withdrawing groups to one of the ligands, which, respectively, lead to destabilization or stabilization of the energies of the ligand orbitals. ${ }^{99}$ More specifically, modifications in NC ligands modulate the energy of HOMO while those in a LX ligand affect the energy of LUMO. ${ }^{100,101}$

These investigations started in 2010 and, since then, many complexes, Figure 9, had their photophysics detailly elucidated. ${ }^{39,102}$ The LFCE was one of the first groups to propose that the degree of SOC-induced mixings in $\mathrm{T}_{1}$ 's excited-state character can also be rationally tuned towards enhancements in the radiative rate constant. ${ }^{95} \mathrm{By}$ this approach, improved emission quantum yields can be reached, as thoroughly discussed and revised. ${ }^{44}$

The emission of complexes Ir- 1 to Ir- 4 varies systematically from blue-green to orange with variations in electron-donating or -withdrawing substituents on both the NN and the NC ligands, Figure 10.95 


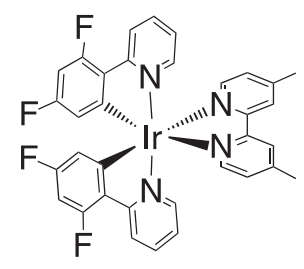

Ir-1
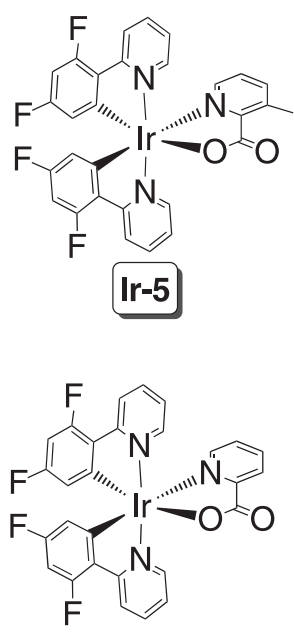

FIrPic

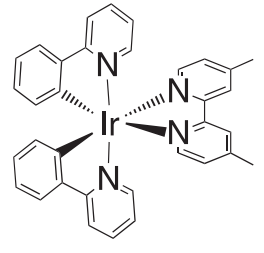

Ir-2
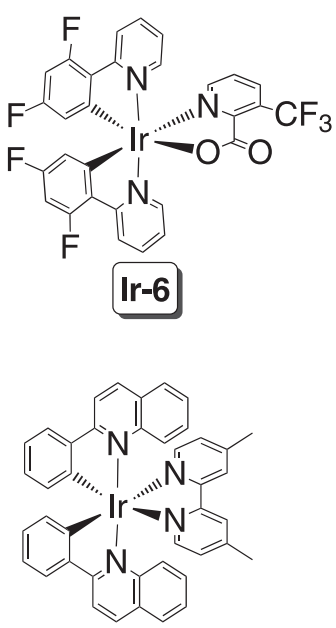

Ir-9

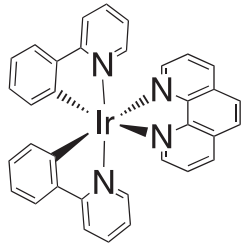

Ir-3
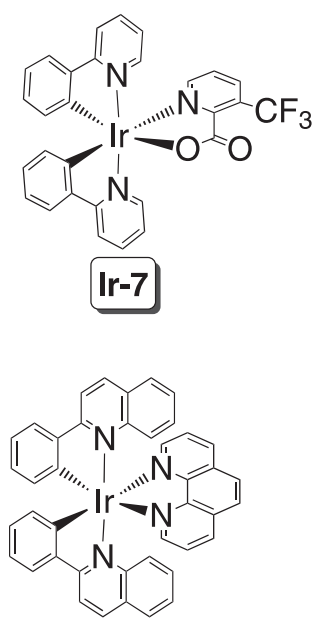

Ir-10

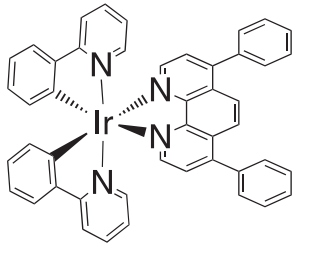

Ir-4
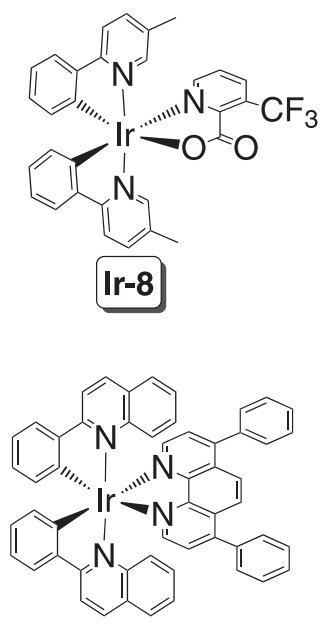

Ir-11

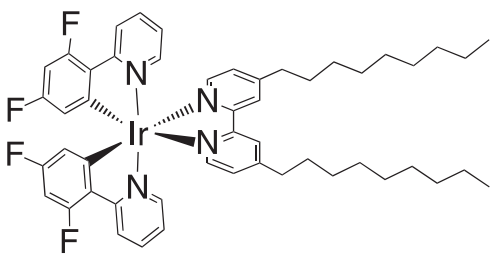

Ir-12

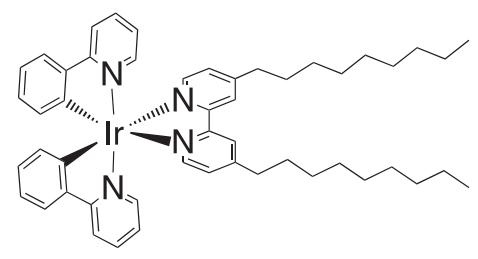

Ir-13

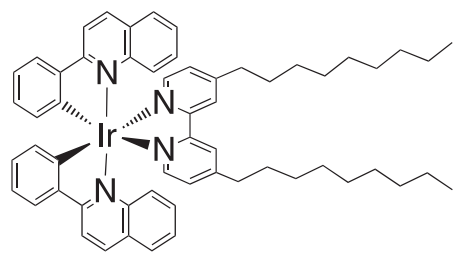

Ir-14

Figure 9. Luminescent $\mathrm{Ir}^{\mathrm{III}}$ complexes investigated by the LFCE for light-emitting systems.

Time-dependent density functional theory (TD-DFT) calculations and Franck-Condon band shape analyses indicated a SOC-induced mixed MLCT/LC character for the emission of Ir-1, which resulted in an emission quantum yield $(\phi)=96 \%$, at least four times higher than that observed for the similar complex Ir-2, with $\phi=23 \%$. Later, complex Ir-5 was synthesized to exhibit blue-sky emission using the strong electron-donating 3-methylpyridine-2-carboxylate (Mepic) ligand, coordinated to $\mathrm{Ir}^{\mathrm{IIII}}$ through NO instead of NN. ${ }^{103}$ Ir-5 was inspired in the archetypal blue emitter FIrPic (see Figure 9), ${ }^{104}$ yet with an additional methyl group in the picolinate ligand to enhance the mixing character in $\mathrm{T}_{1}$ hence increasing $\phi$ from $80 \%$ in FIrPic to $98 \%$ in Ir-5. On the other hand, changing the electron-donating methyl group to the electron-withdrawing $\mathrm{CF}_{3}$ group, as in the Ir- 6 to Ir- 8 series, increased the non-radiative rate constant in detriment to the radiative one, decreasing their $\phi(<13 \%) .{ }^{105}$

The photophysical properties of the series Ir- 9 to Ir-11, with 2-phenylquinoline as cyclometalated NC ligand, were also investigated. ${ }^{106}$ These complexes exhibit high $\phi$ and high efficiency of singlet oxygen photosensitization, showing that they can find use in many applications, from the active layer of electroluminescent devices ${ }^{43,44,48,50,52,91,97,98,107,108}$ to photosensitizers for photodynamic therapy and theranostics. ${ }^{88,90,109-111}$

Complexes Ir-12 to Ir-14 have the ability to produce micelles combining the photophysical properties of Ir-2 to Ir-4. ${ }^{112}$ These complexes were mixed with an appropriate surfactant to result in micelles that served as templates for the synthesis of highly-emissive mesoporous silica host supramolecular materials.

LEC devices were fabricated by employing complexes 

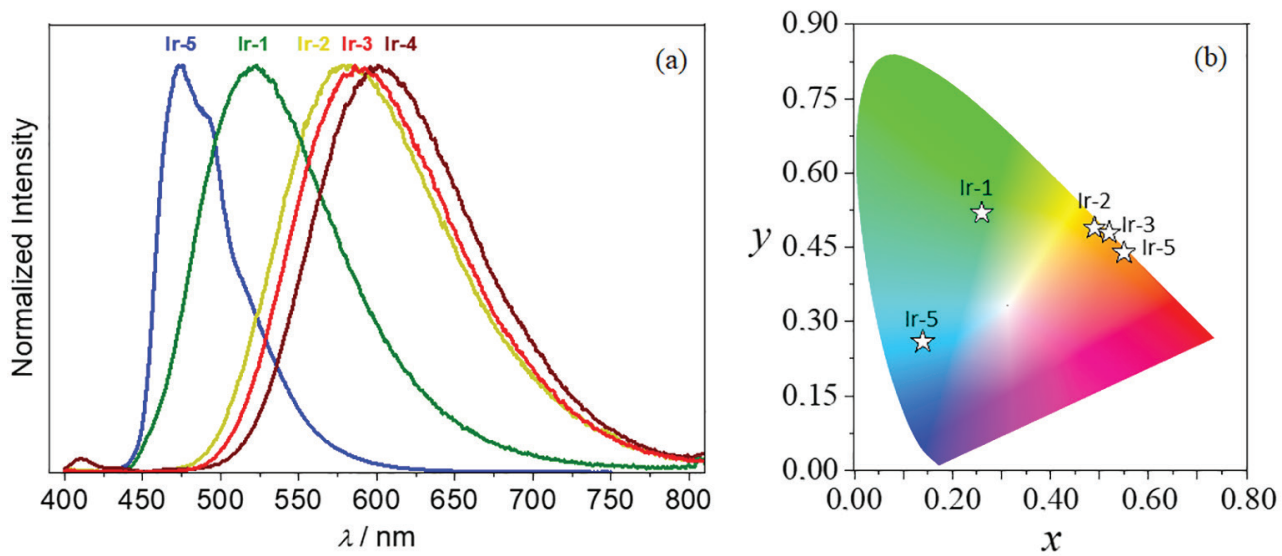

Figure 10. (a) Emission spectra and (b) CIE color coordinates for Ir-1 to Ir-5 in $298 \mathrm{~K}$ fluid acetonitrile.

Ir-1 and Ir-2 as emissive active layers, exhibiting green and yellow light, respectively, Figure $11 .^{113-115}$ The FTO/PEDOT:PSS/Ir-2/Al device was sealed using a treatment developed by the LFCE, ${ }^{116}$ which allowed the optoelectronic characterization to be carried out in air, outside of a glovebox. ${ }^{114}$ A blue-emissive FTO/PEDOT:PSS/PVK:Ir-5/Al OLED was fabricated using Ir-5-doped PVK as the emissive layer. ${ }^{113}$ The PVK:Ir-5 films are subjected to an intense energy transfer from the polymer to the complex, resulting in a complete quenching of the PVK emission. These works are a successful proof of concept for feasible low-cost light-emitting devices with simple architectures and fabrication methods that require non-specific instruments.
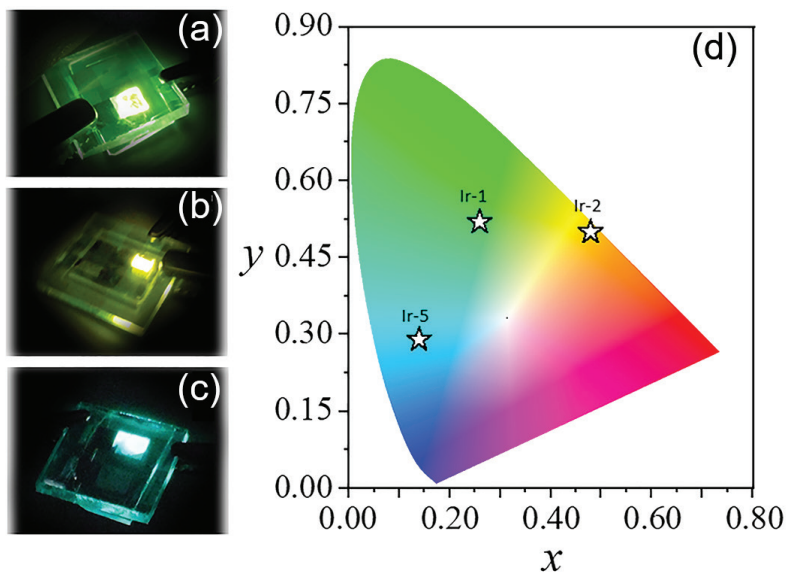

Figure 11. (a) ITO/PEDOT:PSS/Ir-1/Al and (b) ITO/PEDOT:PSS/Ir-2/ Al LECs and (c) ITO/PEDOT:PSS/PVK:Ir-5/Al OLED under operation, with their CIE color coordinates indicated in diagram (d).

\section{Molecular Machines and Photosensors}

3.1. Photochemical and photophysical properties of $R^{1}$ complexes

Those $f a c-\left[\operatorname{Re}(\mathrm{CO})_{3}(\mathrm{NN})(\mathrm{L})\right]^{0 /+}$ complexes mentioned in sub-section 2.2 are also effective in sensitizing the trans $\rightleftharpoons$ cis photoisomerization of stilbene-like molecules (which can coordinate to $\mathrm{Re}^{\mathrm{I}}$ as a monodentate $\mathrm{L}$ ligand), Figure 12. ${ }^{6,79,117-142}$ This photochemical reaction is appealing for allowing molecular geometry control by means of light absorption, ${ }^{5,143}$ which can be conveniently exploited in molecular machines, gears and motors with yes-no or on-off logical responses for applications in sensors and biological systems, such as deoxyribonucleic acid (DNA) transcription ${ }^{144}$ and regulation of cations in membranes..$^{145-147}$ The main advantage of using coordination complexes is to improve and/ or sensitize the photoreaction to the visible region. ${ }^{6}$

(a)
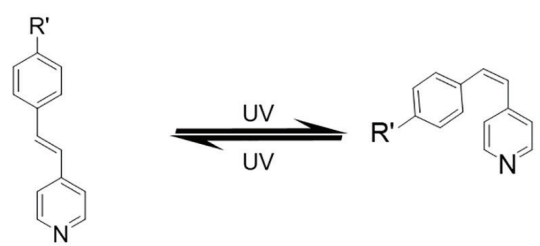

(b)

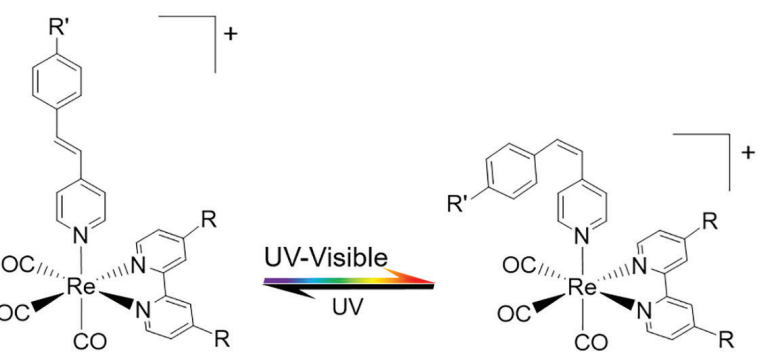

Figure 12. trans $\rightleftharpoons$ cis photoisomerization for (a) free stilbene-like molecules or $(b)$ as a ligand in $f a c-\left[\operatorname{Re}(\mathrm{CO})_{3}(\mathrm{NN})(\mathrm{L})\right]^{+}$complexes.

Absorption of light is restricted to the UV region for the non-coordinated stilbene molecules while the coordination to the $f a c-\left[\operatorname{Re}(\mathrm{CO})_{3}(\mathrm{NN})\right]^{+}$moiety overcomes this limitation, sensitizing the trans $\rightarrow$ cis photoisomerization process toward visible light. ${ }^{6,81,139}$ The photoisomerization mechanism of $f a c-\left[\operatorname{Re}(\mathrm{CO})_{3}(\mathrm{NN})(\text { trans }-\mathrm{L})\right]^{+}$is not straightforward being subject of many investigations. It 
depends not only on the L stilbene-like molecule but also on electronic interactions with the $\mathrm{NN}$ ligand and the $\mathrm{Re}^{\mathrm{I}}$ center (spin-orbit coupling inducer). ${ }^{124,127,129,134,138,148}$ In summary, the absorption of light occurs through singlet excited states, either a ligand-centered ${ }^{1} \mathrm{LC}_{\mathrm{L}}$ transition (equivalent to the $S_{1}$ state in the free organic molecule) in the $\mathrm{UV}$ region or a ${ }^{1} \mathrm{MLCT}_{\mathrm{Re} \rightarrow \mathrm{NN}}$ toward visible. Then, the excited molecule relaxes (by intersystem crossings and/ or internal conversions) to the lowest-lying triplet ligand centered state ${ }^{3} \mathrm{LC}_{\mathrm{L}}$ (equivalent to the $\mathrm{T}_{1}$ state in the free organic molecule), which is now less spin-forbidden due to the influence exerted by the $\mathrm{Re}^{\mathrm{I}}$ core.

trans $\rightarrow$ cis photoisomerization of $f a c-\left[\operatorname{Re}(\mathrm{CO})_{3}(\mathrm{NN})(\mathrm{L})\right]^{+}$ can be properly monitored by UV-Vis and ${ }^{1} \mathrm{H}$ nuclear magnetic resonance (NMR) spectral changes as a function of photolysis time, as exemplified in Figure 13. Upon irradiation, absorption spectral changes usually lead to welldefined isosbestic points, which indicate no competitive photoreactions. ${ }^{6,84,117,121,127,141,149,150}$ Also, ${ }^{1} \mathrm{H}$ NMR signals for the trans-isomer decrease gradually, while new signals ascribed to the $c i s$-isomer build up in intensity. It is noteworthy that the hydrogen coupling constant between
$\mathrm{H}_{\mathrm{c}}$ and $\mathrm{H}_{\mathrm{d}}$ of the trans-isomer is $J^{3}$ ca. $16 \mathrm{~Hz}^{121,123}$ while for $\mathrm{H}_{\mathrm{c}}{ }^{\prime}$ and $\mathrm{H}_{\mathrm{d}}{ }^{\prime}$ in the $c i s$-isomer is $J^{3}$ ca. $12 \mathrm{~Hz}$, ${ }^{6}$ which confirm a successful photoisomerization.

Usually, trans- and cis-isomers absorb in the same region, Figure 13, thus the the photoisomerization quantum yield $(\Phi)$ values determined by UV-Vis spectral change are just apparent. On the other hand, ${ }^{1} \mathrm{H}$ NMR spectroscopy has been successfully proven by the $\mathrm{LFCE}^{121,151}$ to be an important tool to determine accurate quantum yields since the hydrogen signals for photoproducts and reactants appear in very distinct regions, Figure 13. As a consequence, quantum yields so determined are the true ones while those determined by variations in absorption spectra are apparent.

The LFCE has proven that ${ }^{1} \mathrm{H}$ NMR spectroscopy is an important tool to determine accurate quantum yields, since the hydrogen signals for photoproducts and reactants appear in very distinct regions, Figure $13 .^{84,141,150}$

The $c i s$-isomer complex is usually emissive while the trans-isomer is non-emissive, Figure 14, and emission spectral changes can also monitor the photoisomerization process. The gradual increase in emission (ascribed to the lowest-lying ${ }^{3} \mathrm{MLCT}_{c i s-\mathrm{L}(\mathrm{Re} \rightarrow \mathrm{NN})}$ state) via trans $\rightarrow$ cis

(a)

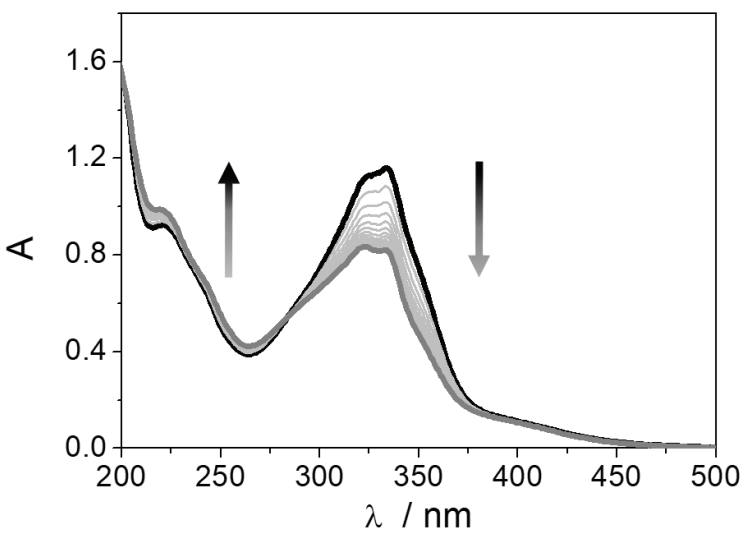

(b)
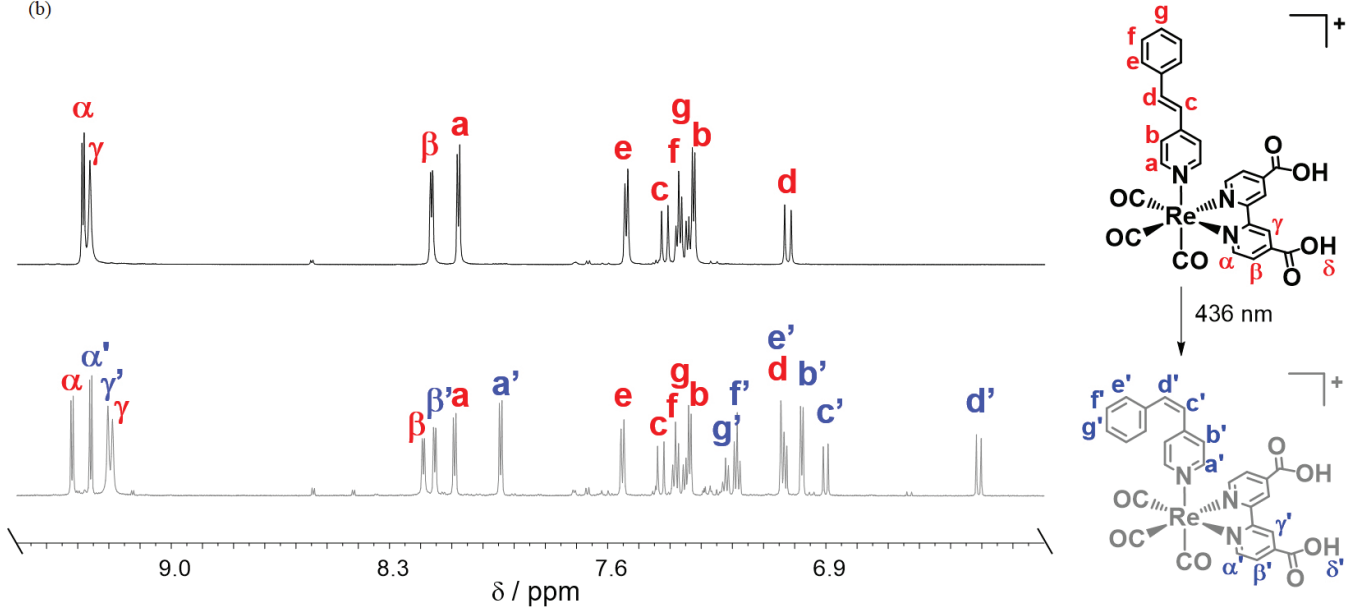

Figure 13. (a) Absorption $\left(\mathrm{CH}_{3} \mathrm{CN}\right)$ and (b) ${ }^{1} \mathrm{H} \mathrm{NMR}\left(800 \mathrm{MHz}, \mathrm{CD}_{3} \mathrm{CN}\right)$ spectral changes for Re-15 as a function of photolysis time $\left(\lambda_{\text {irradiation }}=436 \mathrm{~nm}\right.$, $\Delta \mathrm{t}=30 \mathrm{~s}, \mathrm{~T}=298 \mathrm{~K}$ ). 

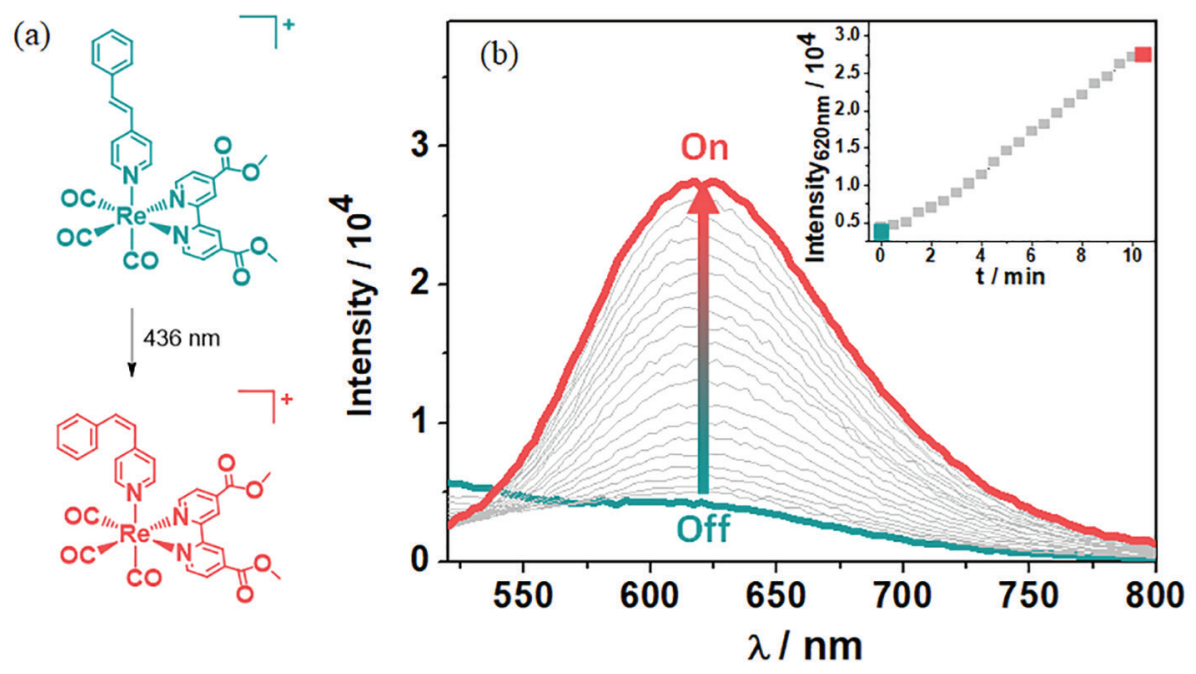

Figure 14. (a) trans-to-cis photosiomerization reaction for Re-14 and (b) changes in its emission $\left(\lambda_{\text {exc }}=420 \mathrm{~nm}\right)$ spectra as a function of photolysis time in acetonitrile $\left(\lambda_{\text {irr }}=436 \mathrm{~nm}, \Delta \mathrm{t}=30 \mathrm{~s}, \mathrm{~T}=298 \mathrm{~K}\right)$. The inset graph in (b) exhibits the increase in the emission intensity at $620 \mathrm{~nm}$ as a function of photolysis time.

photoisomerization can be exploited in the development of optoelectronic devices for photosensors, emission on-off photoswitches and polymerization sensors. ${ }^{117,122,123,125,128,129}$

Figure 15 and Table 2 show fac- $\left[\operatorname{Re}(\mathrm{CO})_{3}(\mathrm{NN})\right.$ $(\text { trans-L) }]^{+}$complexes investigated by the LFCE. The Re-4 to Re-7 bpe series (bpe $=1,2$-bis(4-pyridyl)ethylene) typically exhibits higher trans-to-cis photoisomerization quantum yields $\left(\Phi_{\text {trans } \rightarrow \text { cis }}\right)$ than the non-coordinated ligand, independent on irradiation wavelenghts. . $^{6121,127,148,151-153}$ For example, for complex Re-4 the bpe ligand photoisomerizes under blue light irradiation with outstanding $\Phi_{\text {trans } \rightarrow \text { cis }}$ $\left(\Phi_{313 \mathrm{~nm}}=0.81 \pm 0.07, \Phi_{365 \mathrm{~nm}}=0.80 \pm 0.07\right.$ and $\left.\Phi_{404 \mathrm{~nm}}=0.77 \pm 0.09\right),{ }^{121,148}$ more efficient than the UV restricted non-coordinated bpe $\left(\Phi_{313 \mathrm{~mm}}=0.26 \pm 0.04\right) .{ }^{121}$ Also, an increasing luminescence centered at $570 \mathrm{~nm}$ is observed at room temperature as the cis-isomer is formed. ${ }^{123,131}$

The photoisomerization process was also observed for rhenium(I) binuclear complexes, in which bpe was used as a bridge photoisomerizable ligand attaching both bulk units. Similarly to mononuclear complexes, irradiation of Re-8 led to spectral changes with clear and well defined isosbestic points ascribed to the trans $\rightarrow$ cis photoisomerization. ${ }^{153}$ On the other hand, no photoisomerization was observed for rhenium(II)-iron(II) (Re-9) and rhenium(II)-osmium(I) (Re-10) bimetallic complexes, ${ }^{126,154}$ due to the presence of the lower-lying ${ }^{3} \mathrm{MLCT}$ state of iron $\left({ }^{3} \mathrm{MLCT}_{\mathrm{Fe} \rightarrow \text { bpe }}\right){ }^{154}$ or osmium $\left({ }^{3} \mathrm{MLCT}_{\mathrm{Os} \rightarrow \mathrm{bpe}}\right)^{126}$ that quenches the photoisomerization channel.

Differently than the Re-4 to Re-7 bpe series, the Re-16 to Re-19 stpy series (stpy $=4$-styrylpyridine) exhibit irradiation-wavelength dependent $\Phi_{\text {trans } \rightarrow \text { cis }}$, suggesting different photoisomerization mechanisms, subject of several studies. ${ }^{81,133,134,138}$ The progress of these studies led to the $f a c-\left[\operatorname{Re}(\mathrm{CO})_{3}(\mathrm{NN})(\text { trans-stpyCN)}]^{+}\right.$series $(\operatorname{Re}-20-24)$ achieving the first $\mathrm{Re}^{\mathrm{I}}$ series to present a truly reversible (trans $\rightarrow$ cis and cis $\rightarrow$ trans) photoresponsive molecular motion..$^{84,15,137,141,149}$ This impressive photoreversibility of fac- $\left[\operatorname{Re}(\mathrm{CO})_{3}(\mathrm{NN})(\text { trans-stpyCN })\right]^{+}$opens new perspective for application in molecular machines as molecular motors and geometry regulators for switch on/off devices.

Re-11 and Re-15 complexes were engineered for device applications taking advantage of carboxylic acid as anchoring group. The photochemistry had been investigated both in fluid solution and adsorbed on $\mathrm{TiO}_{2}$ surface with detection of photoisomerization for both complexes independent on the media. The Re-11 cis-photoproduct, emissive in solution, had its emission quenched in favor of electron injection into $\mathrm{TiO}_{2}$, with increasing photocurrent as the concentration of $c i$ s-isomers increases. ${ }^{117}$ The breakthrough of Re-15 is the effective sensitization to the visible with photoisomerization occurring even at $436 \mathrm{~nm}$; in particular, Re-15 exhibits characteristics for solar energy conversion devices. ${ }^{150}$ The undergoing investigation revealed that it adsorbs more efficiently on the $\mathrm{TiO}_{2}$ surface. Furthermore, it is successfully photoisomerized under $436 \mathrm{~nm}$ irradiation, Figure 16. These systems exemplify their use as a proof of concept for molecular devices.

\section{Dye-Sensitized Energy Conversion Devices}

The abundant and potentially infinite energy generated by the sun is one of the most promising sources to supply and complement the world energy matrix, ${ }^{155,156}$ in special in Brazil, where the solar irradiation index is high practically 

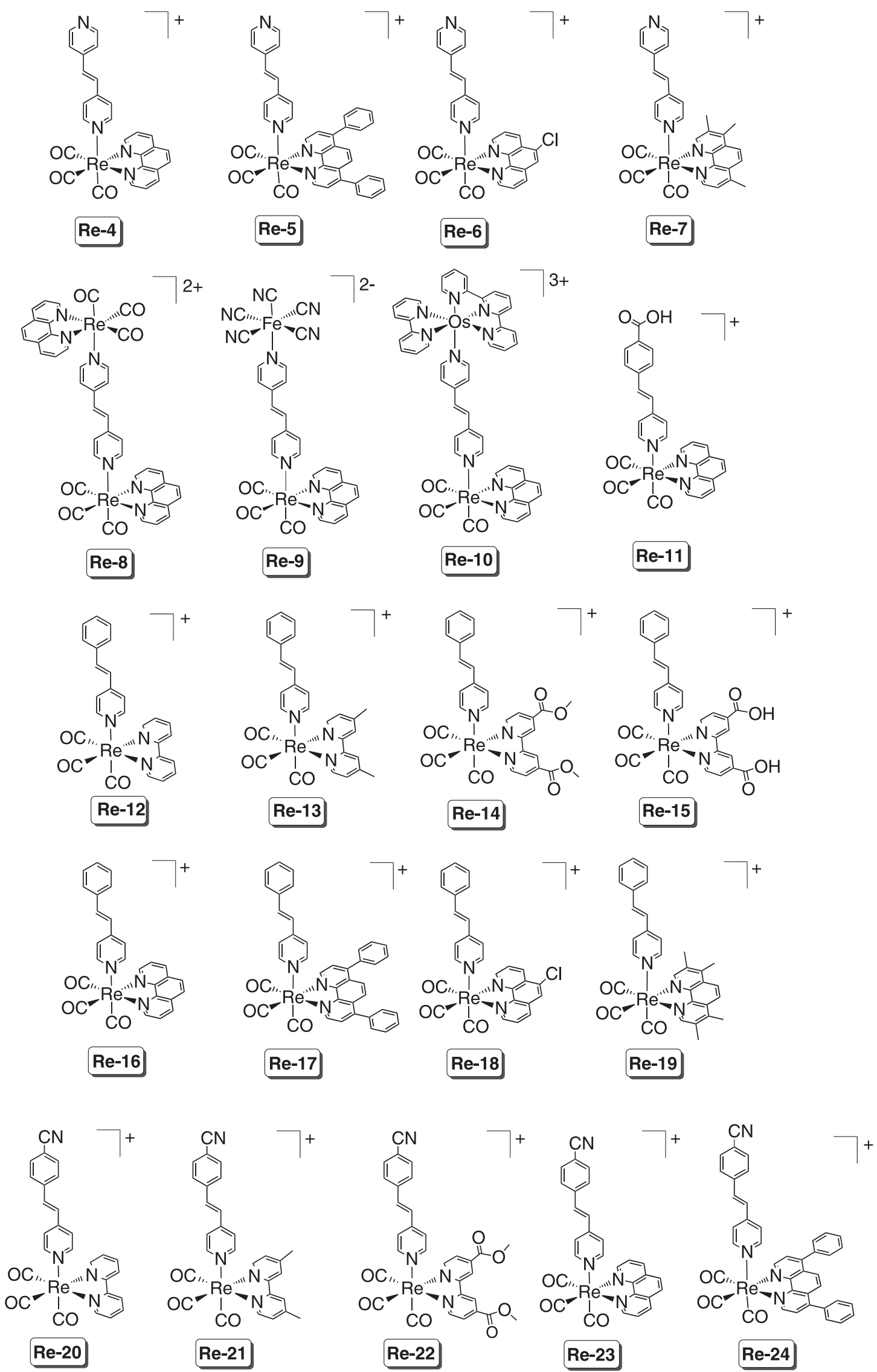

Figure 15. trans $\rightarrow$ cis L photoisomerizable rhenium(I) complexes investigated by the LFCE for photosensors and molecular machines. 
Table 2. trans-cis photoisomerization quantum yields for the $f a c-\left[\operatorname{Re}(\mathrm{CO})_{3}(\mathrm{NN})(\text { trans-L) }]^{+}\right.$complexes investigated by LFCE

\begin{tabular}{|c|c|c|c|c|c|c|}
\hline \multirow{3}{*}{ Compound } & \multicolumn{5}{|c|}{ trans-cis photoisomerization quantum yield } & \multirow{3}{*}{ Reference } \\
\hline & \multicolumn{5}{|c|}{$\lambda$ irradiation } & \\
\hline & $313 \mathrm{~nm}$ & $334 \mathrm{~nm}$ & $365 \mathrm{~nm}$ & $404 \mathrm{~nm}$ & $436 \mathrm{~nm}$ & \\
\hline Re-4 & $0.81 \pm 0.07$ & - & $0.80 \pm 0.07$ & $0.77 \pm 0.09$ & no absorption & 121 \\
\hline Re-5 & $0.43 \pm 0.03$ & - & $0.44 \pm 0.02$ & $0.43 \pm 0.02$ & no absorption & 121 \\
\hline Re-6 & $0.55 \pm 0.03$ & & $0.55 \pm 0.05$ & $0.56 \pm 0.05$ & no absorption & 148 \\
\hline Re-7 & $0.32 \pm 0.05$ & $0.29 \pm 0.04$ & $0.33 \pm 0.04$ & $0.29 \pm 0.03$ & no absorption & 129 \\
\hline Re-11 & $0.64 \pm 0.02$ & - & $0.69 \pm 0.03$ & $0.48 \pm 0.04$ & no absorption & 117 \\
\hline Re-12 & - & - & - & $0.48 \pm 0.03$ & no absorption & 152 \\
\hline Re-13 & - & - & - & $0.31 \pm 0.07$ & no absorption & 152 \\
\hline Re-14 & $0.54 \pm 0.04$ & $0.55 \pm 0.03$ & $0.53 \pm 0.02$ & $0.43 \pm 0.03$ & $0.44 \pm 0.05$ & 149 \\
\hline Re-15 & $0.49 \pm 0.06$ & $0.51 \pm 0.03$ & $0.54 \pm 0.05$ & $0.51 \pm 0.04$ & $0.50 \pm 0.03$ & 150 \\
\hline Re-16 & $0.59 \pm 0.05$ & - & $0.60 \pm 0.06$ & $0.43 \pm 0.02$ & no absorption & 121 \\
\hline Re-17 & $0.60 \pm 0.05$ & - & $0.64 \pm 0.09$ & $0.42 \pm 0.03$ & no absorption & 121 \\
\hline Re-18 & $0.53 \pm 0.02$ & & $0.57 \pm 0.02$ & $0.41 \pm 0.05$ & no absorption & 148 \\
\hline Re-19 & $0.52 \pm 0.06$ & $0.57 \pm 0.05$ & $0.57 \pm 0.06$ & $0.35 \pm 0.02$ & no absorption & 129 \\
\hline Re-20 & $0.44 \pm 0.02$ & $0.44 \pm 0.01$ & $0.45 \pm 0.02$ & $0.39 \pm 0.03$ & no absorption & 84 \\
\hline Re-21 & $0.43 \pm 0.02$ & $0.47 \pm 0.02$ & $0.48 \pm 0.06$ & $0.36 \pm 0.03$ & no absorption & 84 \\
\hline Re-22 & $0.65 \pm 0.05$ & $0.64 \pm 0.04$ & $0.62 \pm 0.05$ & $0.55 \pm 0.05$ & $0.56 \pm 0.04$ & 149 \\
\hline Re-23 & $0.58 \pm 0.05$ & - & $0.61 \pm 0.05$ & $0.42 \pm 0.02$ & no absorption & 137 \\
\hline $\mathrm{Re}-24$ & $0.38 \pm 0.08$ & $0.38 \pm 0.08$ & $0.38 \pm 0.03$ & $0.37 \pm 0.02$ & no absorption & 141 \\
\hline
\end{tabular}

$\lambda$ irradiation: irradiation wavelength.
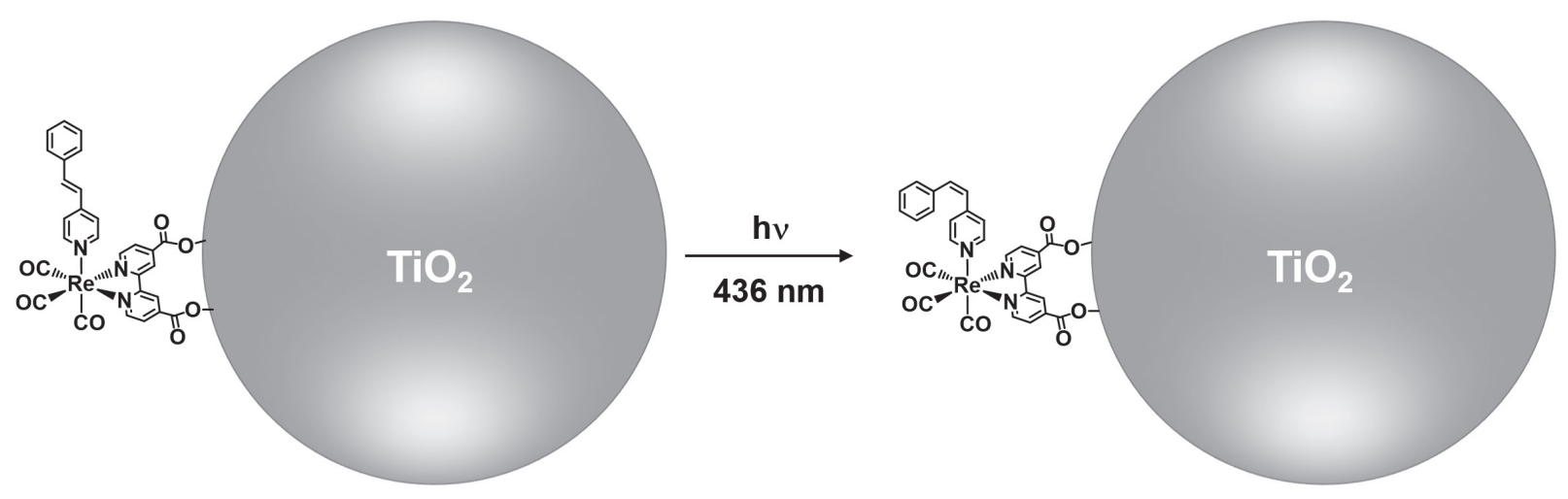

Figure 16. trans-to-cis photoisomerization of Re-15 adsorbed on the $\mathrm{TiO}_{2}$ surface (complex and nanoparticle are out of scale).

throughout the whole year. ${ }^{157}$ Therefore, there is a great interest in developing devices capable of converting solar energy efficiently, as perspectives for sustainable and renewable sources of clean energy. ${ }^{158}$ The LFCE extended investigations on the solar energy field in 1995, with researches on DSCs emerged in collaboration with Prof Carlo A. Bignozzi.

\subsection{Dye-sensitized solar cells}

DSCs belong to the third generation of photovoltaics and their working mechanism makes use of supramolecular approaches for device concepts. ${ }^{158-161}$ Differently from other photovoltaic technologies, DSCs are photoelectrochemical cells in which light-to-electricity conversion occurs via dyes chemically adsorbed on the electrode surface and the separation of charge carriers is kinetically controlled by the chemical reaction involved. ${ }^{162,163}$

The typical DSC is composed by a photoanode and a counter electrode in a sandwich-type arrangement, Figure 17. The photoanode consists in a glass substrate with a transparent conductive oxide (TCO, usually fluorinedoped tin oxide, FTO) on which a mesoporous thin film of a wide bandgap semiconductor oxide (commonly $\mathrm{TiO}_{2}$ ) is deposited. Sensitizers (dyes, e.g., cis-[ $\left.\mathrm{Ru}\left(\mathrm{dcbH}_{2}\right)_{2}(\mathrm{NCS})_{2}\right]$, $\mathrm{N} 3$, or $\left.c i s-\left[\mathrm{Ru}\left(\mathrm{dcbH}_{2}\right)_{2}(\mathrm{NCS})_{2}\right][\mathrm{TBA}]_{2}, \mathrm{~N} 719\right)$ are adsorbed 


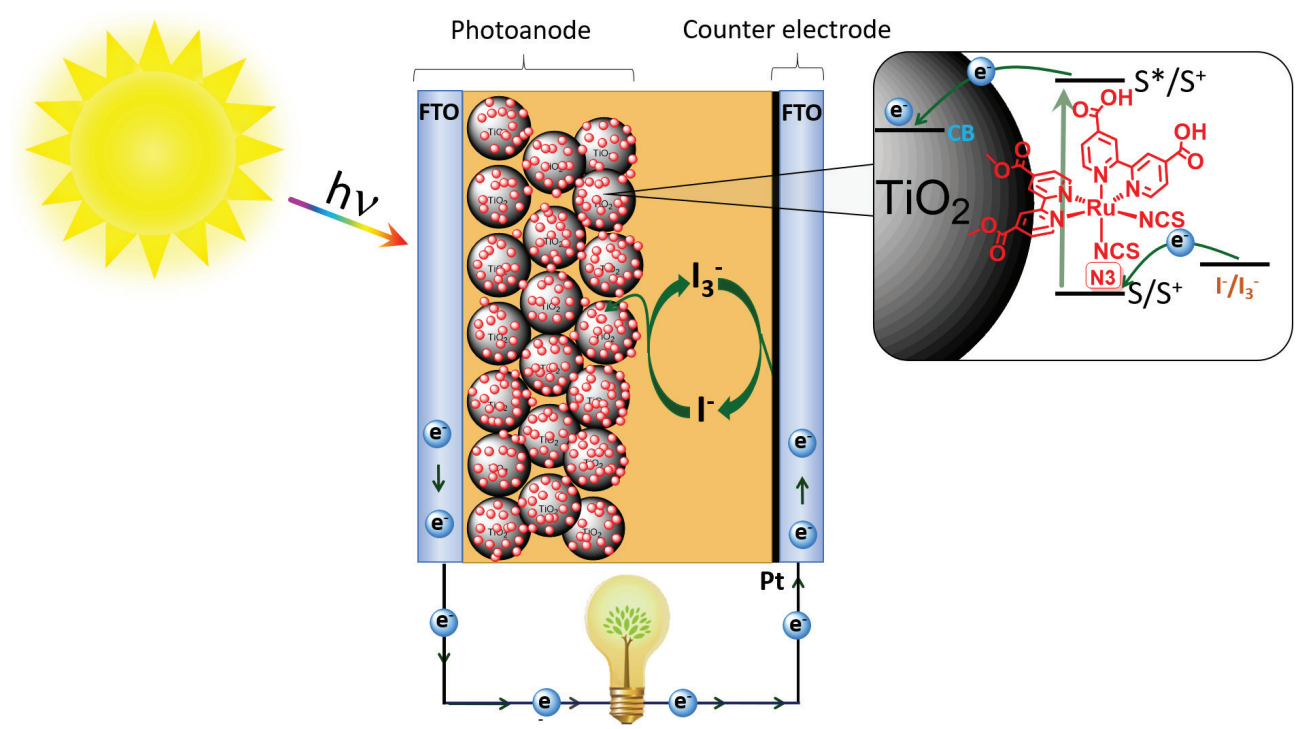

Figure 17. Simplified working mechanism of DSCs (more details in the main text).

on the semiconductor nanoparticles surface to absorb the visible light. The counter electrode consists of a TCO substrate with a thin layer of a catalyzer (usually transparent Pt film). A mediator electrolyte solution is inserted between both electrodes (usually, a concentrated $\mathrm{I}^{-} / \mathrm{I}_{3}^{-}$solution) to complete the regenerative circuit. ${ }^{164,165}$

Under sun shining, the sensitizer dye (S) absorbs solar irradiation to result in excited state $\left(\mathrm{S}^{*}\right)$, which injects electrons to the semiconductor conduction band (CB). The oxidized sensitizer $\left(\mathrm{S}^{+}\right)$is then reduced by the mediator $\mathrm{I}^{-}$, regenerating S. Meanwhile, photoinjected electron percolate through the semiconductor film and is collected at the counter electrode, where a catalyzer reduces $\mathrm{I}_{3}^{-}$to $\mathrm{I}^{-}$, closing the cycle. ${ }^{159,164}$ Therefore, in this regenerative electrochemical device, visible light is efficiently converted into electricity without any permanent chemical change. The highest efficiencies reported so far is around $14.3 \%{ }^{166,167}$ and have proven to be commercially feasible and several products had been released. ${ }^{168,169}$

The LFCE developed several aspects related to the DSC technology, including the pathway from fundamental academic scientific knowledge acquired from research to technological innovation and intellectual protection by patents. ${ }^{170-175}$

These activities included the preparation of colloidal $\mathrm{TiO}_{2}$ using distinct methods and different deposition techniques, such as spin-coating, painting and screenprinting. ${ }^{176,177}$ Homogeneous semiconductor films with controlled transparency had been obtained with the proper colloidal $\mathrm{TiO}_{2}$ for automated process. Conducting plastic materials were also tested as the electrode substrate in association with a polymeric gel as an electrolyte medium resulting in wholly flexible solar cells. The electron transfer from the excited dye to semiconductor and the charge recombination/quenching processes were further investigated by transient UV-Vis absorption spectra on dye-sensitized $\mathrm{TiO}_{2}$ films deposited onto glass substrates. A fast quenching of the oxidized complex in the presence of iodide emphasized the importance of a proper concentration of donor species in the redox mediator for the effective regeneration of the oxidized sensitizer. ${ }^{178,179}$

Molecular engineering of cis-[Ru( $\left.\left.\mathrm{dcbH}_{2}\right)_{2} \mathrm{LL}^{\prime}\right]$ compounds ( $\mathrm{dcbH}_{2}=4,4$ '-dicarboxylic acid-2,2'- bipyridyl and LL' $^{\prime}=$ ancillary ligands) that act as panchromatic charge transfer sensitizers of $\mathrm{TiO}_{2}$ is still in continuous study, Figure 18. Our investigation efforts now progress toward device improvements through new synthetic and natural dyes.

Ruthenium-based dyes are the most-commonly used sensitizers due to their intense (high molar absorptivity) and broad absorption bands in the visible region ascribed to the ${ }^{1} \mathrm{MLCT}_{\mathrm{Ru} \rightarrow \mathrm{NN}}$ transition. They also present high chemical and thermal stability in both ground and oxidized states and have favorable redox potentials for electron injection into $\mathrm{CB}$ of $\mathrm{TiO}_{2}{ }^{180-182}$

The proper selection of ancillary ligands provides the suitable energetic control of the overall properties of these complexes. This approach was successfully applied to improve the incident photon-to-current efficiency (IPCE) and consequent the electron injection into $\mathrm{TiO}_{2}-\mathrm{CB}$ sensitized by complexes Ru-3 to Ru- 6 .

The incident photon-to-current efficiency obtained for Ru-3 (56\%, Table 3) is higher than that for Ru-4 (ca. 40\%). ${ }^{178,183,184}$ The Ru-3 complex, with two different ancillary ligands, presented a broader spectral response at longer wavelengths when compared to the bis-coordinated 


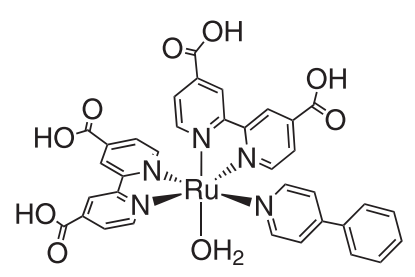

Ru-3

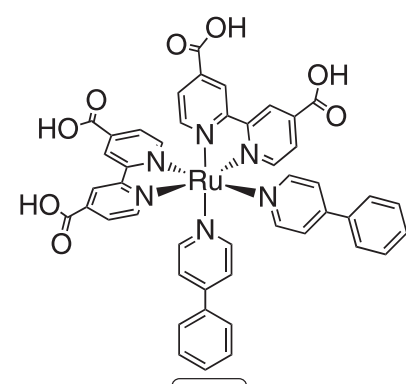

Ru-4

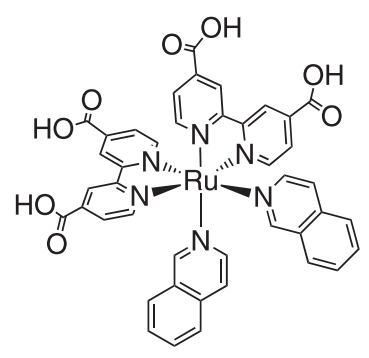

Ru-5

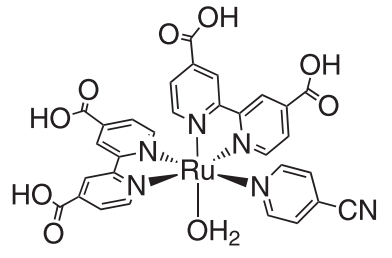

Ru-6

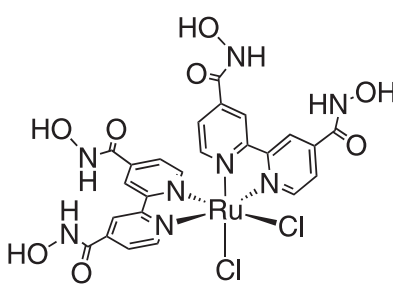

Ru-7

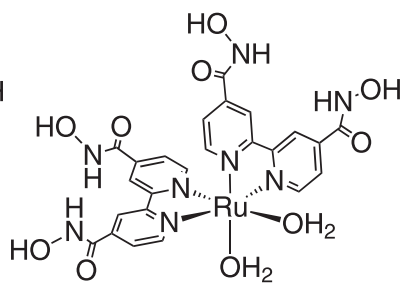

Ru-8

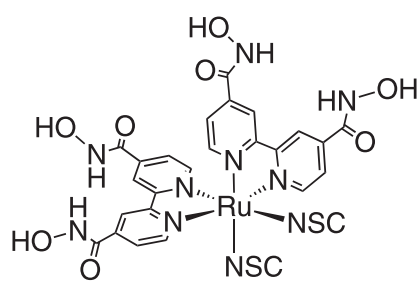

Ru-9

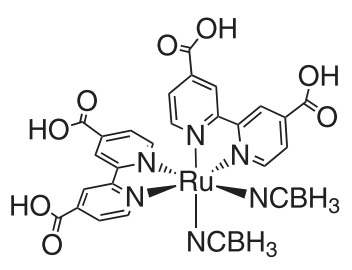

Ru-10

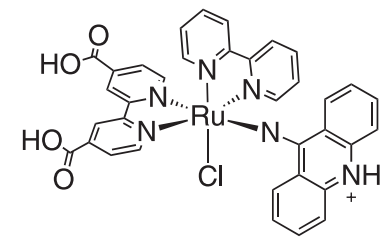

Ru-11

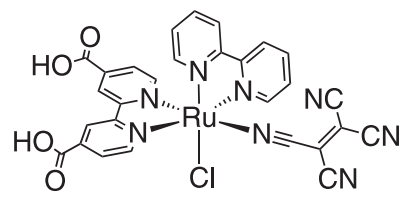

Ru-12

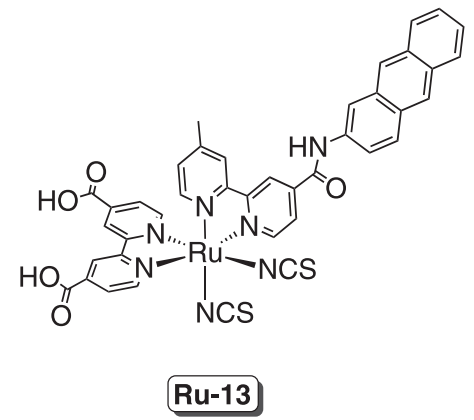

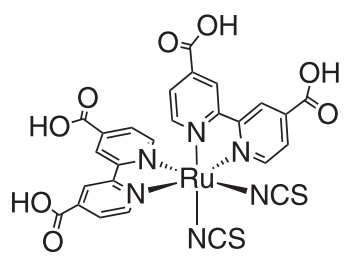

N3

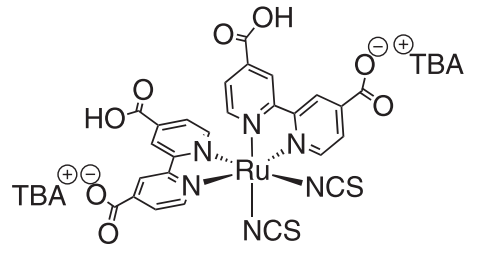

N719

Figure 18. Ruthenium(II) complexes investigated by the LFCE as sensitizers in DSCs.

Table 3. Photoelectrochemical parameters for DSCs sensitized with the ruthenium(II) dyes investigated by the LFCE

\begin{tabular}{|c|c|c|c|c|c|c|}
\hline Complex & $\mathrm{J}_{\mathrm{SC}} /\left(\mathrm{mA} \mathrm{cm}^{-2}\right)$ & $\mathrm{V}_{\mathrm{oc}} / \mathrm{V}$ & $f f$ & $\eta / \%$ & $\mathrm{IPCE}_{\max } / \%$ & Reference \\
\hline $\mathrm{Ru}-3$ & & & & & 56 & $178,183,184$ \\
\hline $\mathrm{Ru}-4$ & & & & & ca. 40 & $178,183,184$ \\
\hline $\mathrm{Ru}-5$ & & & & & ca. 60 & 185 \\
\hline $\mathrm{Ru}-6$ & & & & & ca. 60 & 184 \\
\hline $\mathrm{Ru}-10$ & 8.0 & 0.66 & 0.51 & & & 152 \\
\hline $\mathrm{Ru}-11$ & 3.5 & 0.58 & 0.46 & 0.95 & 25 & 186 \\
\hline Ru-12 & 6.6 & 0.67 & 0.65 & 2.82 & 50 & 186 \\
\hline
\end{tabular}

$\mathrm{J}_{\mathrm{SC}}$ : short-circuit photocurrent density; $\mathrm{V}_{\mathrm{OC}}$ : open-circuit potential; ff: fill factor; $\eta$ : photoconversion efficiency; IPCE: incident photon-to-current efficiency. 
4-phenylpyridine (ppy) derivative Ru-4, showing an important role in the characteristic of the donor ligand in tuning photoelectrochemical properties. The Ru- 6 complex exhibited higher IPCE (ca. 60\%) ${ }^{184}$ when compared with its analogous ppy- (Ru-3 and 4) and isoquinoline-derivatives (Ru-5). ${ }^{185}$

DSCs sensitized by Ru-10 exhibited a fair short-circuit photocurrent density $\left(\mathrm{J}_{\mathrm{SC}}\right)$ of $8.00 \mathrm{~mA} \mathrm{~cm}{ }^{-2}$, open-circuit potential $\left(\mathrm{V}_{\mathrm{OC}}\right)$ of $0.66 \mathrm{~V}$ and fill factor $(f f)$ of $0.51 .{ }^{152}$ Variations in photoelectrochemical parameters obtained for DSCs with Ru-11 and Ru-12 sensitizers were ascribed to the different properties of the ancillary ligands. ${ }^{186}$

Synthetic dyes, such as coordination compounds and organic molecules, usually lead to the best photon conversion efficiencies in DSCs. ${ }^{182,187-189}$ However, the use of certain natural dyes as sensitizers is an advantageous environmental-friendly alternative, for their low toxicity, easy obtention and preparation of low-cost devices. ${ }^{190-196}$ Natural dyes are obtained from different parts of plants, such as fruits, flowers, leaves and roots. ${ }^{197}$ Those used in DSCs usually present an intense blue/violet color ascribed to the presence of anthocyanins with anchoring groups to promote an effective adsorption on $\mathrm{TiO}_{2}$, Figure 19, similarly to the $\mathrm{Ru}^{\mathrm{II}}$-based dyes. ${ }^{182}$ The LFCE investigated DSCs sensitized by many anthocyanin-based fruit-extract: blueberry (Vaccinium myrtillus Lam.), ${ }^{198,199}$ cabbage-palm fruit (Euterpe oleracea Mart.), ${ }^{200}$ calafate (Berberis buxifolia Lam.), ${ }^{201}$ chaste tree fruit (Solanum americanum Mill.), ${ }^{200}$ jaboticaba's skin (Myrtus cauliflora Mart), 198,201,202 java plum (Eugenia jambolana Lam), ${ }^{202,203}$ mulberry (Morus alba L.), ${ }^{198-200,202}$ pomegranate (Punica granatum) ${ }^{202}$ and raspberry (Rubus idaeus L.), ${ }^{199}$ as summarized in Figure 19.

The strategies exploited by the LFCE to enhance the efficiencies of DSCs sensitized by mulberry, jaboticaba's skin, java plum and pomegranate have focused mainly in variating the extraction medium or $\mathrm{pH}$ control. For instance, DSCs sensitized with jaboticaba's skin showed an improvement when water was substituted by ethanol as extraction medium, enhancing the device efficiency up to $115 \%$ ( $\eta$ from 0.47 to $1.15 \%$ ). ${ }^{201}$

Adding pyridine in mediators for DSCs sensitized by anthocyanins resulted in a considerable $\mathrm{J}_{\mathrm{SC}}$ loss. For mulberry, for example, this led to a $79 \%$ decrease in photoconversion efficiency ( $\eta$ from 4.31 to $0.92 \%$ ). ${ }^{200}$ The current drop was due to a decrease in the medium $\mathrm{pH}$, leading to deprotonation of anthocyanin and consequent desorption from the $\mathrm{TiO}_{2}$ surface, as previously observed by Calogero et al. ${ }^{204}$ Therefore, pyridine-free electrolytes are more appropriate for anthocyanin-sensitized DSCs.

The stability of natural-dye-sensitized DSC was also investigated with mulberry, jaboticaba's skin and blueberry. ${ }^{199-201}$ DSCs sensitized by mulberry exhibited constant photoelectrochemical parameters after 14 weeks of continuous evaluation, remaining stable even after 36 weeks with a fairly good efficiency when sealed under proper condition. ${ }^{198}$

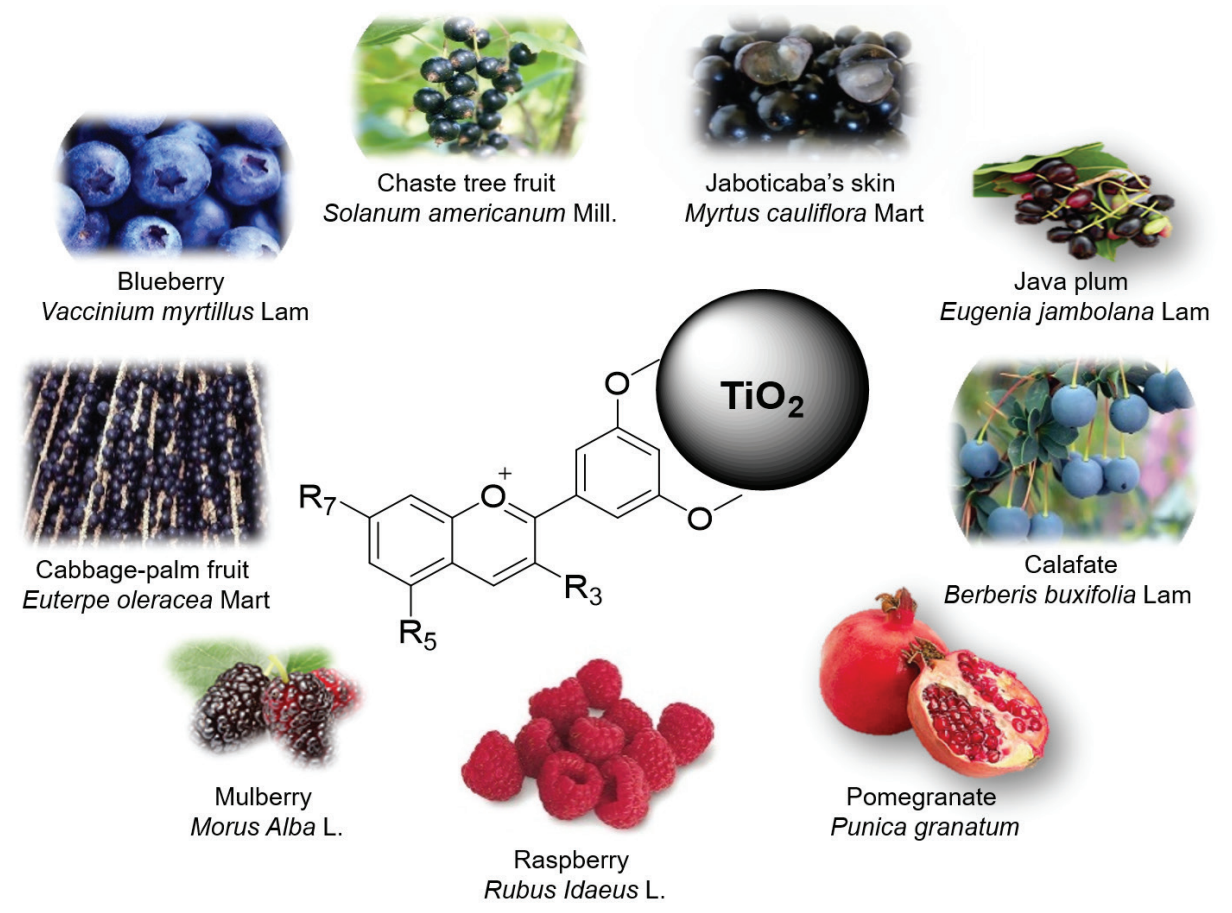

Figure 19. Schematic adsorption of anthocyanin on $\mathrm{TiO}_{2}$ and the fruits investigated by the LFCE. 


\subsection{Dye-sensitized photoelectrosynthesis cells}

Dye-sensitized photoelectrosynthesis cells (DSPECs) use the concepts of DSCs for energy storage. ${ }^{205,206}$ They have been investigated toward the production of solar fuels inspired in natural photosynthesis and referred as artificial photosynthesis. ${ }^{207,208}$ DSPECs can have lowercost production in comparison to other crystallinesemiconductor-based systems for photooxidation of water. ${ }^{209}$ Although a promising strategy, some parallel reactions in their interfaces decrease considerably their efficiency. ${ }^{210}$ Researches on this field are usually focused on new materials and understanding of these phenomena for decreasing electronic recombination from the mesoporous semiconductor to the oxidized dye and diminishing the time the photoinjected electrons take to reach the TCO substrate. ${ }^{211}$

The operation mechanism of a DSPEC is similar to a DSC, in which a sensitizer molecule is excited to a higherenergy state that injects electrons in the conduction band of a semiconductor oxide (usually $\mathrm{TiO}_{2}$ ), initiating a series of molecular and interfacial electron transfer processes to lead to the production of the photoproducts (solar fuels), with higher chemical energy content, ${ }^{206,208,212}$ Figure 20.

The LFCE, in collaboration with Prof Thomas J. Meyer and his research group from the University of North Carolina at Chapel Hill, investigated reactivity toward water oxidation in a class of molecules whose properties can be systematically tuned by synthetic variations based on mechanistic insights. ${ }^{213}$ These molecules work as catalyst for the water oxidation driven either electrochemically or by $\mathrm{Ce}^{\mathrm{IV}}$. The first two, $\left[\mathrm{Ru}(\mathrm{tpy})(\mathrm{bpm})\left(\mathrm{OH}_{2}\right)\right]^{2+}$ and $\left[\mathrm{Ru}(\mathrm{tpy})(\mathrm{bpz})\left(\mathrm{OH}_{2}\right)\right]^{2+}\left(\mathrm{bpm}=2,2^{\prime}\right.$ - bipyrimidine and tpy $=2,2$ ':6',2' -terpyridine), undergo hundreds of turnovers without decomposition using $\mathrm{Ce}^{\mathrm{IV}}$ as oxidant. Detailed mechanistic studies and DFT calculations revealed a stepwise mechanism, addressed in our previous work. ${ }^{213}$ In a brief summary, there is an initial $2 \mathrm{e}^{-} / 2 \mathrm{H}^{+}$oxidation of the $\mathrm{Ru}^{\mathrm{IV}}-\mathrm{H}_{2} \mathrm{O}$ center leading to $\mathrm{Ru}^{\mathrm{IV}}=\mathrm{O}^{2+}$ followed by oxidation to $\mathrm{Ru}^{\mathrm{V}}=\mathrm{O}^{3+}$. A nucleophilic attack by $\mathrm{H}_{2} \mathrm{O}$ gives $\mathrm{Ru}^{\mathrm{III}}-\mathrm{OOH}^{2+}$ with further oxidation to $\mathrm{Ru}^{\mathrm{IV}}\left(\mathrm{O}_{2}\right)^{2+}$ leading to oxygen loss followed by coordination of another water molecule, regenerating the initial $\mathrm{Ru}^{\mathrm{IV}}-\mathrm{H}_{2} \mathrm{O}$ center. An extended family of the catalyst series based on tpy and Mebimpy (Mebimpy = 2,6-bis(1-methylbenzimidazol2-yl)pyridine) ligands shares a common mechanism. ${ }^{213}$ Interfacial dynamics at the derivatized $\mathrm{TiO}_{2}\left(\mathrm{TiO}_{2}-\mathrm{Ru}^{\mathrm{II}}\right)$ were also investigated under appropriate condition to water oxidation, by means of nanosecond laser flash photolysis. ${ }^{214}$

The water oxidation catalyst $\left[\mathrm{Ru}(\mathrm{bda})\left(4-\mathrm{O}\left(\mathrm{CH}_{2}\right)_{3} \mathrm{P}-\right.\right.$ $\left(\mathrm{O}_{3} \mathrm{H}_{2}\right)_{2}$-py $\left.)_{2}\right]$, (py = pyridine and bda $=2,2$ ' -bipyridine6,6'-dicarboxylate) in a series of chromophore-catalyst assemblies has been investigated as light-driven water splitter in DSPECs. ${ }^{215}$ Device performance for both coloaded and layer-by-layer assemblies with phosphonate$\mathrm{Zr}^{\mathrm{IV}}$ bridging on $\mathrm{SnO}_{2} / \mathrm{TiO}_{2}$ core-shell electrodes was evaluated by both photocurrent and direct $\mathrm{O}_{2}$ measurements in collector-generator cells. The photoelectrodes displayed favorable photocurrents $\left(0.72-1.5 \mathrm{~mA} \mathrm{~cm}^{-2}\right)$ and Faradaic efficiencies for $\mathrm{O}_{2}$ generation (71-97\%), providing

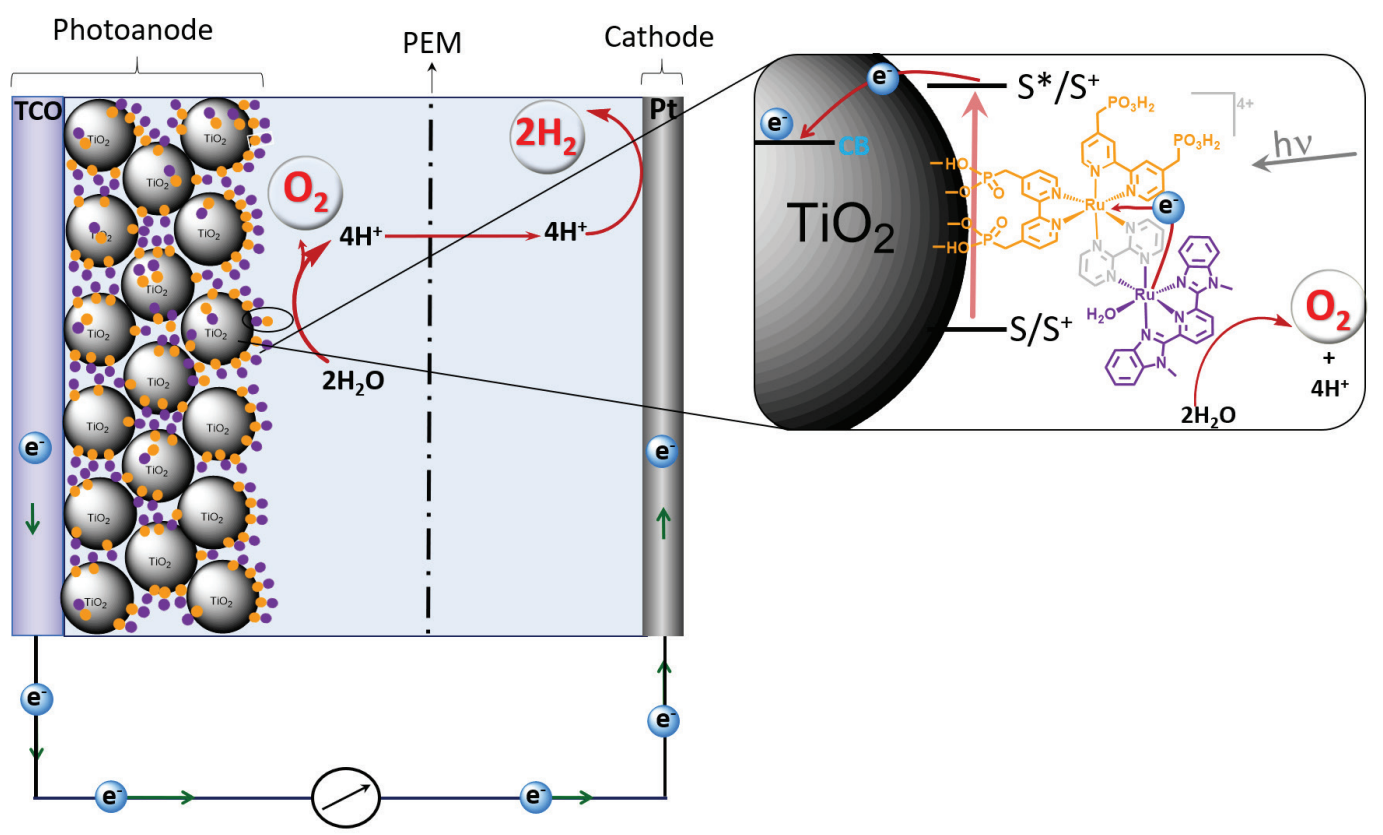

Figure 20. Main components, device architecture and simplified mechanism of a DSPEC for light-driven water oxidation and proton reduction under operation (more details in the main text). PEM is a proton exchange membrane. 
important mechanistic insights into the microscopic details for DSPEC water splitting. ${ }^{215}$

\subsection{Photoanode engineering}

DSCs based on nanocrystalline mesoporous semiconductors, in special $\mathrm{TiO}_{2}$, have been extensively investigated since $1991^{216}$ with continuous improvement. For high performance DSCs, the desired characteristics of mesoporous films are a high specific surface area with good porosity, long electron diffusion length and a pronounced light scattering effect. ${ }^{217}$

One of approaches of photoanode engineering is integrating small nanocrystallites into one single bifunctional film with advantages of increased light scattering and dye-loading, by using mesoporous microspherical titania particles comprised of small nanocrystallites. ${ }^{218-221}$ The development of a screen-printable paste with improved morphological and optical characteristics for the automated deposition of submicrometer $\mathrm{TiO}_{2}$ resulted in $32 \%$ enhanced conversion efficiency. ${ }^{176,177}$

Another successful approach is the photoanode engineering to minimize recombination effects by treating the $\mathrm{TiO}_{2}$ or FTO surface with a thin cover layer of compact semiconductor oxide ${ }^{222}$ or even insulating oxide ${ }^{223}$ that efficiently blocks charge recombination decreasing power conversion efficiencies. ${ }^{224}$

The recombination at FTO/electrolyte interface occurs through the direct physical contact between the FTO and the mediator that percolates through the mesoporous $\mathrm{TiO}_{2}$ semiconductor film. This can be decreased with the use of a compact layer obtainable by many deposition techniques, such as spray-pyrolysis, ${ }^{225}$ sputtering, ${ }^{226}$ dip-coating, ${ }^{227-229}$ spin-coating, ${ }^{230}$ atomic-layer deposition ${ }^{231,232}$ and layer-by-layer (LbL). ${ }^{233}$ In particular, the LbL technique is a low-cost procedure for a thin film deposition that offers rigorous control of morphology with possibility of scaling up and applications in different areas. ${ }^{234-237}$ This technique is based on the electrostatic interactions between oppositely charged materials; therefore a chosen substrate, as FTO, is immersed into cationic and anionic solutions (or suspensions) in a cyclic procedure, ${ }^{238}$ as shown in Figure 21.

Our first approach using LbL assemblages started with $\mathrm{TiO}_{2}$ nanoparticles as cations pairing with polyelectrolytes, such as sodium sulfonated polystyrene (PSS), sulfonated lignin (SL) and poly(acrylic acid) (PAA), as anions. ${ }^{239,240}$ The nature of polyelectrolyte had a key role on the efficiency of N3-sensitized DSCs, with the best performance achieved by the use of the $\mathrm{TiO}_{2} / \mathrm{PSS}$ compact layer, that increased the overall efficiency of DSCs in $30 \%$, Table $4 .{ }^{240}$ The lower thermal stability of PAA resulted in a more porous film and, therefore, unable to block the contact of electrolyte and the FTO substrate.

A nanostructured thin film consisted of $\mathrm{TiO}_{2} / \mathrm{ZnO}$ bilayers from acid $\mathrm{TiO}_{2}$ and basic $\mathrm{ZnO}$ had also been successfully applied as a blocking and contact layer. This film revealed a significant improvement in the $\mathrm{J}_{\mathrm{SC}}$ and $\mathrm{V}_{\mathrm{OC}}$, leading to a remarkable $67 \%$ improvement in the conversion efficiency of N3-sensitized DSCs. ${ }^{242}$

The innovative ultrathin LbL all-nano- $\mathrm{TiO}_{2}$ film as an interfacial layer created excellent adhesion of the $\mathrm{TiO}_{2}$ layer on the FTO substrate ${ }^{245}$ leading to an efficient

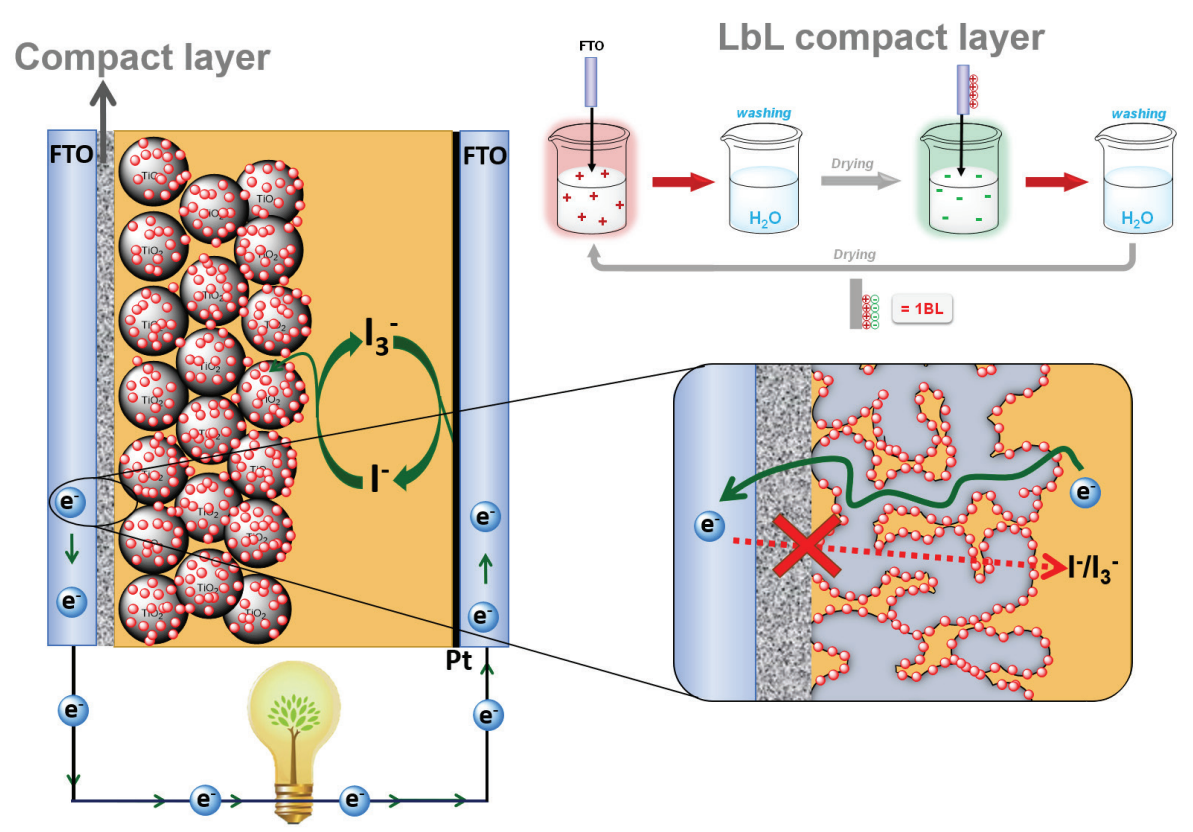

Figure 21. Transparent DSC improved with compact layers assembled using opposite charged nanoparticle by the LbL technique. 
electronic transport from $\mathrm{TiO}_{2}$ to $\mathrm{FTO}$ and consequent impressive enhancement up to $62 \%$ in performances of N719-sensitized DSCs. ${ }^{243}$ This nano- $\mathrm{TiO}_{2}$ compact layer when employed in DSCs sensitized by mulberry, jaboticaba's skin, java plum and pomegranate fruit led to enhanced global efficiencies up to $66 \% .^{202}$

The LbL deposition of nano- $\mathrm{TiO}_{2}$ compact layers on the underlying mesoporous oxide had been successfully employed in DSPECs leading to an impressive improvement of 53\% for photocurrent with additional enhancements of sustainable currents over time photolysis with characteristics favoring $\mathrm{O}_{2}$ evolution at the photoanode. This innovative approach in DSPECs with a significant impact on the device performance provided a suitable platform to decrease back electron reactions and/or improve the electron collection at the photoanode due to an improved insulation at the back contact, opening up new possibilities of gathering suitable molecular assemblies using a low-cost deposition method for thin films to enhance the performance of water-splitting devices. $^{246}$

\section{Technological Innovation and Closing Remarks}

The development within the framework of supramolecular chemistry gives rise to the possibility of designing organized systems and components of molecular level devices. This organization is particularly interesting for building molecular assemblies capable of performing useful functions, such as energy conversion/storage, information purpose and lightning-devices.

The multidisciplinary but fundamental research outlined herein resulted in innovation and technological developments, as well as proof of concept for several

Table 4. Photoelectrochemical parameters for LbL-compact film improved DSCs investigated by the LFCE

\begin{tabular}{|c|c|c|c|c|c|c|c|c|}
\hline Compact layer & $\begin{array}{c}\text { Mesoporous } \\
\text { layer }\end{array}$ & Dye & $\mathrm{J}_{\mathrm{sc}} /\left(\mathrm{mA} \mathrm{cm}{ }^{-2}\right)$ & $\mathrm{V}_{\mathrm{oc}} / \mathrm{V}$ & $f f$ & $\eta / \%$ & $\begin{array}{c}\text { Efficiency } \\
\text { improvement / \% }\end{array}$ & Reference \\
\hline- & \multirow{2}{*}{ a } & \multirow{2}{*}{ N3 } & $10.2 \pm 0.5$ & $0.68 \pm 0.02$ & $0.64 \pm 0.03$ & $5.7 \pm 0.3$ & & \multirow{2}{*}{239} \\
\hline $\mathrm{TiO}_{2} / \mathrm{PSS}$ & & & $12.6 \pm 0.5$ & $0.73 \pm 0.01$ & $0.62 \pm 0.03$ & $7.3 \pm 0.3$ & 28 & \\
\hline- & \multirow{4}{*}{ a } & \multirow{4}{*}{ N3 } & $13.0 \pm 0.8$ & $0.66 \pm 0.02$ & $0.66 \pm 0.01$ & $5.6 \pm 0.5$ & & \multirow{4}{*}{240} \\
\hline $\mathrm{TiO}_{2} / \mathrm{PSS}$ & & & $15.8 \pm 0.3$ & $0.70 \pm 0.01$ & $0.67 \pm 0.01$ & $7.3 \pm 0.1$ & 30 & \\
\hline $\mathrm{TiO}_{2} / \mathrm{SL}$ & & & $15.0 \pm 0.5$ & $0.68 \pm 0.01$ & $0.69 \pm 0.01$ & $6.9 \pm 0.3$ & 23 & \\
\hline $\mathrm{TiO}_{2} / \mathrm{PAA}$ & & & $11.8 \pm 0.3$ & $0.69 \pm 0.01$ & $0.72 \pm 0.04$ & $5.8 \pm 0.3$ & 3 & \\
\hline- & \multirow{2}{*}{ a } & \multirow{2}{*}{ N3 } & $8.3 \pm 0.1$ & $0.67 \pm 0.01$ & $0.57 \pm 0.01$ & $3.3 \pm 0.1$ & & \multirow{2}{*}{241} \\
\hline $\mathrm{TiO}_{2} / \mathrm{Nb}_{2} \mathrm{O}_{5}$ & & & $13.9 \pm 0.1$ & $0.70 \pm 0.00$ & $0.60 \pm 0.01$ & $6.2 \pm 0.1$ & 87 & \\
\hline- & \multirow{2}{*}{ a } & \multirow{2}{*}{ N3 } & $9.6 \pm 0.1$ & 0.670 .01 & $0.71 \pm 0.01$ & $4.9 \pm 0.1$ & & \multirow{2}{*}{242} \\
\hline $\mathrm{TiO}_{2} / \mathrm{ZnO}$ & & & $15.6 \pm 0.3$ & $0.70 \pm 0.01$ & $0.70 \pm 0.02$ & $8.2 \pm 0.2$ & 67 & \\
\hline- & \multirow{2}{*}{ a } & \multirow{2}{*}{ N719 } & $15.2 \pm 0.7$ & $0.75 \pm 0.01$ & $0.62 \pm 0.02$ & $7.1 \pm 0.3$ & & \multirow{2}{*}{243} \\
\hline $\mathrm{TiO}_{2} / \mathrm{TiO}_{2}$ & & & $16.4 \pm 0.9$ & $0.74 \pm 0.01$ & $0.64 \pm 0.04$ & 11.5 & 62 & \\
\hline- & \multirow{2}{*}{ a } & \multirow{2}{*}{ N3 } & $10.8 \pm 0.3$ & $0.47 \pm 0.01$ & $0.52 \pm 0.01$ & $2.68 \pm 0.01$ & & \multirow{2}{*}{202} \\
\hline $\mathrm{TiO}_{2} / \mathrm{TiO}_{2}$ & & & $15.1 \pm 0.2$ & $0.51 \pm 0.01$ & $0.57 \pm 0.01$ & $4.38 \pm 0.12$ & 63 & \\
\hline- & \multirow{2}{*}{ a } & \multirow{2}{*}{ mulberry } & $4.31 \pm 0.21$ & $0.38 \pm 0.01$ & $0.56 \pm 0.01$ & $0.90 \pm 0.02$ & & \multirow{2}{*}{202} \\
\hline $\mathrm{TiO}_{2} / \mathrm{TiO}_{2}$ & & & $6.08 \pm 0.23$ & $0.40 \pm 0.01$ & $0.62 \pm 0.02$ & $1.49 \pm 0.04$ & 66 & \\
\hline- & \multirow{2}{*}{ a } & \multirow{2}{*}{ jaboticaba's skin } & $3.59 \pm 0.14$ & $0.34 \pm 0.00$ & $0.48 \pm 0.03$ & $0.59 \pm 0.03$ & & \multirow{2}{*}{202} \\
\hline $\mathrm{TiO}_{2} / \mathrm{TiO}_{2}$ & & & $5.17 \pm 0.02$ & $0.36 \pm 0.00$ & $0.52 \pm 0.02$ & $0.98 \pm 0.03$ & 6 & \\
\hline- & \multirow{2}{*}{$\mathrm{a}$} & \multirow{2}{*}{ java plum } & $2.57 \pm 0.11$ & $0.37 \pm 0.01$ & $0.47 \pm 0.03$ & $0.53 \pm 0.05$ & & \multirow{2}{*}{202} \\
\hline $\mathrm{TiO}_{2} / \mathrm{TiO}_{2}$ & & & $4.03 \pm 0.13$ & $0.38 \pm 0.01$ & $0.58 \pm 0.01$ & $0.85 \pm 0.01$ & 6 & \\
\hline- & \multirow{2}{*}{ a } & \multirow{2}{*}{ pomegranate } & $2.44 \pm 0.39$ & $0.38 \pm 0.01$ & $0.53 \pm 0.01$ & $0.50 \pm 0.01$ & & 00 \\
\hline $\mathrm{TiO}_{2} / \mathrm{TiO}_{2}$ & & & $3.36 \pm 0.36$ & $0.41 \pm 0.01$ & $0.52 \pm 0.01$ & $0.71 \pm 0.01$ & 42 & 202 \\
\hline- & a & & $8.0 \pm 0.3$ & $0.69 \pm 0.01$ & $0.73 \pm 0.02$ & $4.0 \pm 0.2$ & & \\
\hline $\mathrm{TiO}_{2} / \mathrm{TiO}_{2}$ & a & N3 & $11.2 \pm 0.2$ & $0.72 \pm 0.01$ & $0.72 \pm 0.02$ & $5.8 \pm 0.2$ & 45 & 176 \\
\hline- & h & 13 & $10.7 \pm 0.1$ & $0.73 \pm 0.02$ & $0.75 \pm 0.03$ & $5.9 \pm 0.1$ & & \\
\hline $\mathrm{TiO}_{2} / \mathrm{TiO}_{2}$ & b & N3 & $15.1 \pm 0.3$ & $0.74 \pm 0.04$ & $0.72 \pm 0.01$ & $8.0 \pm 0.3$ & 36 & 176 \\
\hline- & 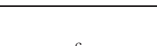 & ?רת & $11.3 \pm 0.2$ & $0.75 \pm 0.01$ & $0.74 \pm 0.02$ & $6.3 \pm 0.2$ & & \\
\hline $\mathrm{TiO}_{2} / \mathrm{TiO}_{2}$ & & N3 & $15.9 \pm 0.3$ & $0.75 \pm 0.01$ & $0.75 \pm 0.03$ & $9.0 \pm 0.4$ & 43 & 176 \\
\hline- & a & & $2.56 \pm 0.57$ & $0.56 \pm 0.02$ & $0.71 \pm 0.11$ & $1.00 \pm 0.10$ & & \\
\hline $\mathrm{TiO}_{2} / \mathrm{TiO}_{2}$ & $\mathrm{a}$ & Ru-13 & $3.83 \pm 0.44$ & $0.57 \pm 0.01$ & $0.78 \pm 0.02$ & $1.71 \pm 0.14$ & 71 & 244 \\
\hline
\end{tabular}

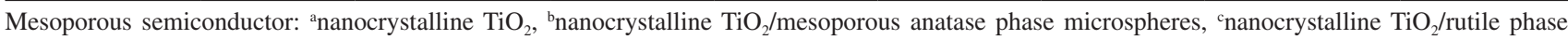
microspheres. $\mathrm{J}_{\mathrm{SC}}$ : short-circuit photocurrent density; $\mathrm{V}_{\mathrm{OC}}$ : open-circuit potential; ff: fill factor; $\eta$ : photoconversion efficiency. 
applications, such as luminescence-based sensors and displays, photoresponsive polymers, visible sensitization of solar cells and photoelectrosynthesis devices.

Contacts with industries/companies led to the first trademark (Dye-Cell ${ }^{\circledR}$ ) of the University of São Paulo in $2001^{247}$ and some patents for intellectual protection. In this occasion, the project developed at the LFCE had been selected by the Brazilian Ministry of Science and Technology (MCT) as an innovative project/product in the energy sector, and took part during the whole year of 2002 in a series of events entitled "Exhibition of Innovative Technological Products for Energy Production". In 2002, one of the patents received São Paulo State Governor honorable mention award. From 2006 to 2008, the development of dye-sensitized solar cells was supported by Petrobras/CNPES till the end of the company renewable program. During these 2 years, several prototypes had been assembled and the feasibility of the device proven.

The development of solar cells became the main subject of a special program called CIUPE (Interinstitutional Collaborative Program for Strategic Researches), which was supported by the University of São Paulo and attracted researchers from several areas in the development of photovoltaics and had provided encouragement for cooperative efforts among different laboratories. ${ }^{248}$

Research on OLEDs and LECs focused on multicolor, highly-emissive complexes and new techniques for device fabrication. For this purpose, many phosphorescent coordination compounds have played a prominent role in several applications. Recent breakthroughs and the state of the art on highly-efficient emissive complexes elucidating the role of molecular and electronic structures to control photophysics in light-emitting systems had been reported in the pursuit of smart white-emitting devices. ${ }^{44}$

A successful molecular engineering of coordination complexes and supramolecular assemblies in many applications of systems cited here is inspiring and illustrates the fascinating strategies to conceive and understand artificial photoresponsive or highly emissive compounds. Future molecular design strategies must head beyond energy and color control.

\section{Acknowledgments}

This work was supported by Fundação de Amparo à Pesquisa do Estado de São Paulo (FAPESP), Coordenação de Aperfeiçoamento de Pessoal de Nível Superior (CAPES) - finance code 001 and Conselho Nacional de Desenvolvimento Científico e Tecnológico (CNPq/ CTEnerg).

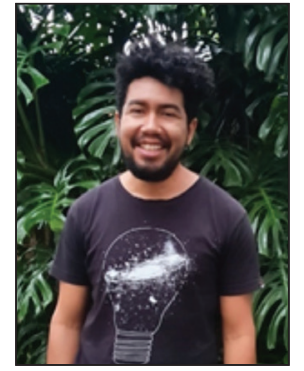

Ronaldo Costa Amaral received his BSc degree in Chemistry from the Universidade Federal Rural do Rio de Janeiro and is a PhD student since 2014 under the supervision of Prof Neyde Yukie Murakami Iha at the IQ-USP. Currently, he is also a lecturer at the Instituto Federal de Educação, Ciência e Tecnologia de São Paulo campus Sorocaba. His research interests include the development of nanostructured materials and coordination compounds for energy conversion devices

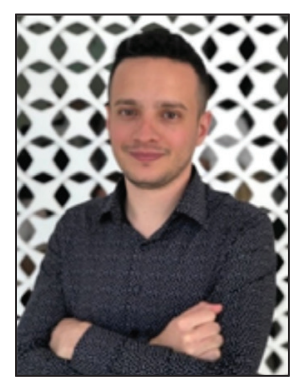

Kassio Papi Silva Zanoni received his $P h D$ in Chemistry from IQ-USP, Brazil, in 2016, supervised by Prof Neyde Yukie Murakami Iha, with an one-year abroad-internship in the University of North Carolina, USA. He was a postdoctoral researcher in Instituto de Física de São Carlos-USP from 2016 to 2019 in collaboration with LFCE in the first 2 years. Currently, he is a postdoctoral researcher at the Universidad de Valéncia, Spain. His main interests lie on molecular engineering and photobehavior of coordination compounds, as well as on fabrication and characterization of optoelectronics, as light-emitting devices and photovoltaic cells.

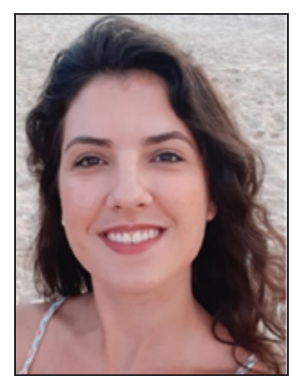

Lais Sottili Matos received her BSc degree in Chemistry from the Universidade Federal de Santa Catarina and is a PhD student since 2014 under the supervision of Prof Neyde Yukie Murakami Iha at the IQ-USP. She deals with the development of nanomaterials for DSCs and the application of polypyridinic complexes of $R e^{I}$ in thin films for optoelectronic devices.

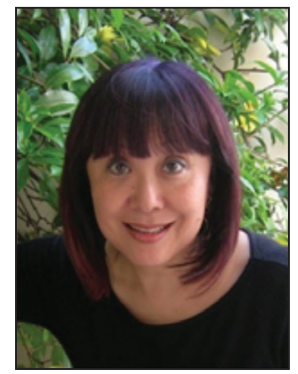

Neyde Yukie Murakami Iha received her BSc, MSc (supervisor: Prof Helena Li Chum) and PhD (supervisor: Prof Henrique Eisi Toma) degrees from the Universidade de São Paulo, Brazil, and did postdoctoral work at the Ochanomizu University, Japan, and at the Radiation Laboratory, 
University of Notre Dame, USA. She is an Associated Professor at the Instituto de Química, University of São Paulo (IQ-USP) and Coordinator of the Laboratory of Photochemistry and Energy Conversion. She has over 90 papers published in well-cited high-impact-factor scientific journals. Her research interests include photochemistry and photophysics of photoresponsive species, in particular, coordination compounds, photoluminescent sensor, molecular machines and light-emitting devices as well as assemblies for solar energy conversion and storage, artificial photosynthesis and solar fuels.

\section{References}

1. Lehn, J.-M.; Angew. Chem., Int. Ed. 1985, 24, 799.

2. Lehn, J.-M.; Chem. Soc. Rev. 2007, 36, 151.

3. Toma, H. E.; An. Acad. Bras. Cienc. 2000, 72, 5.

4. Toma, H. E.; J. Braz. Chem. Soc. 2003, 14, 845.

5. Erbas-Cakmak, S.; Leigh, D. A.; McTernan, C. T.; Nussbaumer, A. L.; Chem. Rev. 2015, 115, 10081.

6. Polo, A. S.; Itokazu, M. K.; Frin, K. M.; Patrocínio, A. O. T.; Murakami Iha, N. Y.; Coord. Chem. Rev. 2006, 250, 1669.

7. Vogler, A.; Kunely, H. In Photosensitization and Photocatalysis Using Inorganic and Organometallic Compounds; Kalyanasundaram, K.; Grätzel, M., eds.; Springer: Netherlands, 1993, p. 71-111.

8. Vogler, A.; Kunkely, H.; Coord. Chem. Rev. 1998, 177, 81.

9. Vogler, A.; Kunkely, H.; Coord. Chem. Rev. 2004, 248, 273.

10. Vos, J. G.; Pryce, M. T.; Coord. Chem. Rev. 2010, 254, 2519.

11. Balzani, V.; Bergamini, G.; Campagna, S.; Puntoriero, F.; Top. Curr. Chem. 2007, 280, 1.

12. Balzani, V.; Credi, A.; Venturi, M.; Coord. Chem. Rev. 1998, 171,3 .

13. Murakami Iha, N. Y.; Toma, H. E.; An. Acad. Bras. Cienc. 1982, 54,491 .

14. Murakami Iha, N. Y.; Toma, H. E.; Inorg. Chim. Acta 1984, 71, 181.

15. Murakumi Iha, N. Y.; Ferreira, A. M. C.; Toma, H. E.; Gallotti, M.; Proc. Annu. Meet. Coord. Chem. 1984, 34, 386.

16. Toma, H. E.; Ferreira, A. M. C.; Murakami Iha, N. Y.; Nouv. J. Chim. 1985, 9, 473.

17. Murakami Iha, N. Y.; Chum, H. L.; Inorg. Chim. Acta 1985, 97 , 151.

18. Murakami Iha, N. Y.; Toma, H. E.; Rev. Latinoam. Quim. 1984, 15,20 .

19. Murakami Iha, N. Y.: Reatividade de Ligantes na Química dos Cianoferratos; PhD Thesis, University of São Paulo, São Paulo, Brazil, 1981, available at https://www.teses.usp.br/ teses/disponiveis/46/46134/tde-28112014-153806/pt-br.php, accessed in May 2020.

20. Toma, H. E.; Murakami Iha, N. Y.; Inorg. Chem. 1982, 21, 3573.
21. Murakami Iha, N. Y.; Lima, J. F.; Toma, H. E.; Proc. Annu. Meet. Coord. Chem. 1984, 34, 116.

22. Murakami Iha, N. Y.; Toma, H. E.; Lima, J. F.; Polyhedron 1988, 7, 1687.

23. Toma, H.; Moroi, N. M.; Murakami Iha, N. Y.; An. Acad. Bras. Cienc. 1982, 54, 315.

24. Lima, J. F.: Reações de Fotossubstituição em Complexos Pentacianoferrato(II), Master dissertation, University of São Paulo, São Paulo, Brazil, 1990, available at https://repositorio. usp.br/single.php?_id=000733870 accessed in May 2020.

25. Garcia, C. G.; de Lima, J. F.; Murakami Iha, N. Y.; Coord. Chem. Rev. 2000, 196, 219.

26. Murakami Iha, N. Y.; Lima, J. F.; J. Photochem. Photobiol., A 1994, 84, 177.

27. Lima, J. F.; Murakami Iha, N. Y.; Can. J. Chem. 1996, 476480.

28. Lima, J. F.: Reatividade Fotoquimica dos Cianocomplexos de Ferro(II) e de Sistemas Multicomponentes, $\mathrm{PhD}$ thesis, University of São Paulo, São Paulo, Brazil, 1996, available at https:// repositorio.usp.br/item/000747325 accessed in May 2020.

29. McCleverty, J. A.; Meyer, T. J.; Comprehensive Coordination Chemistry II, Vol. 2: Fundamentals: Physical Methods, Theoretical Analysis, and Case Studies; Elsevier: Amsterdam, North-Holland, 2003, p. 785-796.

30. Lees, A. J.; Chem. Rev. 1987, 87, 711.

31. Chen, P.; Meyer, T. J.; Chem. Rev. 1998, 98, 1439.

32. Schubert, E. F.; Science 2005, 308, 1274.

33. Chang, M. H.; Das, D.; Varde, P. V.; Pecht, M.; Microelectron. Reliab. 2012, 52, 762.

34. Steranka, F. M.; Bhat, J.; Collins, D.; Cook, L.; Craford, M. G.; Fletcher, R.; Gardner, N.; Grillot, P.; Goetz, W.; Keuper, M.; Khare, R.; Kim, A.; Krames, M.; Harbers, G.; Ludowise, M.; Martin, P. S.; Misra, M.; Mueller, G.; Mueller-Mach, R.; Rudaz, S.; Shen, Y.-C.; Steigerwald, D.; Stockman, S.; Subramanya, S.; Trottier, T.; Wierer, J. J.; Phys. Status Solidi 2002, 194, 380.

35. Schubert, E. F.; Kim, J. K.; Luo, H.; Xi, J.-Q.; Rep. Prog. Phys. 2006, 69, 3069.

36. Wasisto, H. S.; Prades, J. D.; Gülink, J.; Waag, A.; Appl. Phys. Rev. 2019, 6, 041315.

37. Wang, Q.; Tian, Q. S.; Zhang, Y. L.; Tang, X.; Liao, L. S.; J. Mater. Chem. C 2019, 7, 11329.

38. Yersin, H.; Rausch, A. F.; Czerwieniec, R.; Hofbeck, T.; Fischer, T.; Coord. Chem. Rev. 2011, 255, 2622.

39. Evans, R. C.; Douglas, P.; Winscom, C. J.; Coord. Chem. Rev. 2006, 250, 2093.

40. Shahnawaz, S.; Swayamprabha, S. S.; Nagar, M. R.; Yadav, R. A. K.; Gull, S.; Dubey, D. K.; Jou, J. H.; J. Mater. Chem. C 2019, 7, 7144.

41. Salehi, A.; Fu, X.; Shin, D. H.; So, F.; Adv. Funct. Mater. 2019 , 29, 1808803.

42. Minaev, B.; Baryshnikov, G.; Agren, H.; Phys. Chem. Chem. Phys. 2014, 16, 1719. 
43. Xu, H.; Huang, W.; Liu, X.; Chem. Soc. Rev. 2014, 43, 3259.

44. Zanoni, K. P. S.; Coppo, R. L.; Amaral, R. C.; Murakami Iha, N. Y.; Dalton Trans. 2015, 44, 14559.

45. Slinker, J.; Bernards, D.; Houston, P. L.; Abruña, H. D.; Bernhard, S.; Malliaras, G. G.; Chem. Commun. 2003, 2003, 2392.

46. Rudmann, H.; Shimada, S.; Rubner, M. F.; J. Appl. Phys. 2003, 94, 115.

47. Schulz, L.; Nuccio, L.; Willis, M.; Desai, P.; Shakya, P.; Kreouzis, T.; Malik, V. K.; Bernhard, C.; Pratt, F. L.; Morley, N. A.; Suter, A.; Nieuwenhuys, G. J.; Prokscha, T.; Morenzoni, E.; Gillin, W. P.; Drew, A. J.; Nat. Mater. 2011, 10, 39.

48. Su, H.; Chen, Y.; Wong, K.; Adv. Funct. Mater. 2019, 1906898.

49. Zhao, J.; Chi, Z. Z.; Yang, Z.; Chen, X.; Arnold, M. S.; Zhang, Y.; Xu, J.; Chi, Z. Z.; Aldred, M. P.; Aldreda, M. P.; Nanoscale 2018, 10, 5764.

50. Gao, J.; ChemPlusChem 2018, 83, 183.

51. Su, H. C.; ChemPlusChem 2018, 83, 197.

52. Kong, S. H.; Lee, J. I.; Kim, S.; Kang, M. S.; ACS Photonics 2018, 5, 267.

53. Angerani, S.; Winssinger, N.; Chem. - Eur. J. 2019, 25, 6661.

54. Roundhill, D. M. In Photochemistry and Photophysics of Metal Complexes; Springer: Boston, USA, 1994, p. 165-215.

55. Huynh, M. H. V.; Meyer, T. J.; Chem. Rev. 2007, 107, 5004.

56. Kalyanasundaram, K.; Coord. Chem. Rev. 1982, 46, 159.

57. Bock, C. R.; Meyer, T. J.; Whitten, D. G.; J. Am. Chem. Soc. 1974, 96, 4710.

58. Thompson, D. W.; Ito, A.; Meyer, T. J.; Pure Appl. Chem. 2013, $85,1257$.

59. Balzani, V.; Bergamini, G.; Marchioni, F.; Ceroni, P.; Coord. Chem. Rev. 2006, 250, 1254.

60. Xiang, H.; Cheng, J.; Ma, X.; Zhou, X.; Chruma, J. J.; Chem. Soc. Rev. 2013, 42, 6128.

61. Santos, G.; Fonseca, F. J.; Andrade, A. M.; Patrocínio, A. O. T.; Mizoguchi, S. K.; Murakami Iha, N. Y.; Peres, M.; Simões, W.; Monteiro, T.; Pereira, L.; J. Non-Cryst. Solids 2008, 354, 2571.

62. Santos, G.; Fonseca, F.; Andrade, A. M.; Patrocínio, A. O. T.; Mizoguchi, S. K.; Murakami Iha, N. Y.; Peres, M.; Monteiro, T.; Pereira, L.; Phys. Status Solidi 2008, 205, 2057.

63. Lo, K. K. W.; Zhang, K. Y.; Li, S. P. Y.; Eur. J. Inorg. Chem. 2011, 3551.

64. Hostachy, S.; Policar, C.; Delsuc, N.; Coord. Chem. Rev. 2017, 172.

65. Lo, K. K.-W.; Choi, A. W.-T.; Law, W. H.-T.; Dalton Trans. 2012, 41, 6021.

66. Lo, K. K.-W.; Louie, M.-W.; Zhang, K. Y.; Coord. Chem. Rev. 2010, 254, 2603.

67. Lo, K. K.-W. W.; Acc. Chem. Res. 2015, 48, 2985.

68. Balasingham, R. G.; Coogan, M. P.; Thorp-Greenwood, F. L.; Dalton Trans. 2011, 40, 11663.
69. Lo, K. K.-W.; Top. Organomet. Chem. 2010, 29, 115.

70. Kou, Y.; Nabetani, Y.; Masui, D.; Shimada, T.; Takagi, S.; Tachibana, H.; Inoue, H.; J. Am. Chem. Soc. 2014, 136, 6021.

71. Ci, C.; Carbó, J. J.; Neumann, R.; de Graaf, C.; Poblet, J. M.; ACS Catal. 2016, 6, 6422.

72. Wolcan, E.; Inorg. Chim. Acta 2020, 509, 119650.

73. Ragone, F.; Saavedra, H. H. M. M.; Gara, P. M. D. D.; Ruiz, G. T.; Wolcan, E.; J. Phys. Chem. A 2013, 117, 4428.

74. Kumar, A.; Sun, S.-S.; Lees, A. J.; Top. Organomet. Chem. 2009, 48, 37.

75. Zhao, G.-W.; Zhao, J.-H.; Hu, Y.-X.; Zhang, D.-Y.; Li, X.; Synth. Met. 2016, 212, 131.

76. Panigati, M.; Mauro, M.; Donghi, D.; Mercandelli, P.; Mussini, P.; de Cola, L.; D'Alfonso, G.; Coord. Chem. Rev. 2012, 256, 1621.

77. Mizoguchi, S. K.; Santos, G.; Andrade, A. M.; Fonseca, F. J.; Pereira, L.; Murakami Iha, N. Y.; Synth. Met. 2011, 161, 1972.

78. Wrighton, M.; Morse, D. L.; David, L.; J. Am. Chem. Soc. 1974, 96, 998.

79. Campagna, S.; Puntoriero, F.; Nastasi, F.; Bergamini, G.; Balzani, V. In Photochemistry and Photophysics of Coordination Compounds I; Springer: Heidelberg, Berlin, 2007, p. 117-214.

80. Rohacova, J.; Ishitani, O.; Dalton Trans. 2017, 46, 8899.

81. Kayanuma, M.; Daniel, C.; Köppel, H.; Gindensperger, E.; Coord. Chem. Rev. 2011, 255, 2693.

82. Murakami Iha, N.; Ferraudi, G.; J. Chem. Soc., Dalton Trans. 1994, 2565.

83. Mizoguchi, S. K.; Patrocínio, A. O. T.; Murakami Iha, N. Y.; Synth. Met. 2009, 159, 2315.

84. Amaral, R. C.; Matos, L. S.; Zanoni, K. P. S.; Murakami Iha, N. Y.; J. Phys. Chem. A 2018, 122, 6071.

85. Ma, D.-L.; Wong, S.-Y.; Kang, T.-S.; Ng, H.-P.; Han, Q.-B.; Leung, C.-H.; Methods 2019, 168, 3.

86. Abbas, S.; Din, I.-D.; Raheel, A.; ud Din, A. T.; Appl. Organomet. Chem. 2020, 34, e5413.

87. Lan, M.; Zhao, S.; Liu, W.; Lee, C. S.; Zhang, W.; Wang, P.; Adv. Healthcare Mater. 2019, 8, 1900132.

88. Huang, H.; Banerjee, S.; Sadler, P. J.; ChemBioChem 2018, 19 , 1574.

89. Ma, D.; Wu, C.; Wu, K.; Leung, C.; Molecules 2019, 24, 2739.

90. Konkankit, C. C.; Marker, S. C.; Knopf, K. M.; Wilson, J. J.; Dalton Trans. 2018, 47, 9934.

91. Baranoff, E.; Yum, J. H.; Graetzel, M.; Nazeeruddin, M. K.; J. Organomet. Chem. 2009, 694, 2661.

92. Mayo, E. I.; Kilså, K.; Tirrell, T.; Djurovich, P. I.; Tamayo, A.; Thompson, M. E.; Lewis, N. S.; Gray, H. B.; Photochem. Photobiol. Sci. 2006, 5, 871.

93. Hopmann, K. H.; Bayer, A.; Coord. Chem. Rev. 2014, $268,59$. 94. Schultz, D. M.; Yoon, T. P.; Science 2014, 343, 1239176.

95. Zanoni, K. P. S.; Kariyazaki, B. K.; Ito, A.; Brennaman, M. K.; Meyer, T. J.; Murakami Iha, N. Y.; Inorg. Chem. 2014, 53, 4089. 
96. Nazeeruddin, M. K.; Grätzel, M.; Struct. Bonding 2007, 123, 113.

97. Rota Martir, D.; Zysman-Colman, E.; Coord. Chem. Rev. 2018, $364,86$.

98. Li, T. Y.; Wu, J.; Wu, Z. G.; Zheng, Y. X.; Zuo, J. L.; Pan, Y.; Coord. Chem. Rev. 2018, 374, 55.

99. Tsuboi, T.; Huang, W.; Isr. J. Chem. 2014, 54, 885.

100. Cortés-Arriagada, D.; Sanhueza, L.; González, I.; Dreyse, P.; Toro-Labbé, A.; Phys. Chem. Chem. Phys. 2015, 18, 726.

101. Deaton, J. C.; Castellano, F. N. In Iridium(III) in Optoelectronic and Photonics Applications; Zysman-Colman, E., ed.; John Wiley \& Sons Ltd.: Chichester, UK, 2017, p. 1-69

102. Ulbricht, C.; Beyer, B.; Friebe, C.; Winter, A.; Schubert, U. S.; Adv. Mater. 2009, 21, 4418.

103. Zanoni, K. P. S.; Ito, A.; Murakumi Iha, N. Y.; New J. Chem. 2015, 39, 6367.

104. Baranoff, E.; Curchod, B. F. E.; Dalton Trans. 2015, 44, 8318.

105. Coppo, R. L.; Zanoni, K. P. S.; Murakami Iha, N. Y.; Polyhedron 2019, 163, 161.

106. Zanoni, K. P. S.; Ito, A.; Grüner, M.; Murakami Iha, N. Y.; de Camargo, A. S. S.; Dalton Trans. 2018, 47, 1179.

107. Chi, Y.; Tong, B.; Chou, P.-T. T.; Coord. Chem. Rev. 2014, 281, 1.

108. Housecroft, C. E.; Constable, E. C.; Coord. Chem. Rev. 2017, $350,155$.

109. Lee, L. C. C.; Leung, K. K.; Lo, K. K. W.; Dalton Trans. 2017, 46, 16357.

110. Chen, M.; Wu, Y.; Liu, Y.; Yang, H.; Zhao, Q.; Li, F.; Biomaterials 2014, 35, 8748.

111. Jiang, W.; Gao, Y.; Sun, Y.; Ding, F.; Xu, Y.; Bian, Z.; Li, F.; Bian, J.; Huango, C.; Inorg. Chem. 2010, 49, 3252.

112. Zanoni, K. P. S.; Vilela, R. R. C.; Silva, I. D. A.; Murakami Iha, N. Y.; Eckert, H.; de Camargo, A. S.; Inorg. Chem. 2019, 58, 4962.

113. Zanoni, K. P. S.; Murakami Iha, N. Y.; Synth. Met. 2016, 222, 393.

114. Zanoni, K. P. S.; Sanematsu, M. S.; Murakami Iha, N. Y.; Inorg. Chem. Commun. 2014, 43, 162.

115. Zanoni, K. P. S.: Compostos de Coordenação de Ir(III), Re(I) $e$ $R u(I I)$ para Aplicações em Dispositivos Moleculares, $\mathrm{PhD}$ thesis, University of São Paulo, São Paulo, Brazil, 2016, available at https://www.teses.usp.br/teses/disponiveis/46/46136/tde27042018-081643/pt-br.php, accessed in May 2020.

116. Murakami Iha, N. Y.; Mizoguchi, S. K.; BR pat. 018090056741 , 2013.

117. Patrocinio, A. O. T.; Frin, K. P. M.; Murakami Iha, N. Y.; Inorg. Chem. 2013, 52, 5889.

118. Lewis, J. D.; Perutz, R. N.; Moore, J. N.; Chem. Commun. 2000, 1,1865 .

119. Kayanuma, M.; Daniel, C.; Gindensperger, E.; Can. J. Chem. 2014, 92, 979.
120. Itokazu, M. K.; Sarto Polo, A.; Murakami Iha, N. Y.; J. Photochem. Photobiol., A 2003, 160, 27.

121. Frin, K. P. M.; Itokazu, M. K.; Murakami Iha, N. Y.; Inorg. Chim. Acta 2010, 363, 294.

122. Wenger, O. S.; Henling, L. M.; Day, M. W.; Winkler, J. R.; Gray, H. B.; Polyhedron 2004, 23, 2955.

123. Itokazu, M. K.; Polo, A. S.; Murakami Iha, N. Y.; Int. J. Photoenergy 2001, 3, 143.

124. Dattelbaum, D. M.; Itokazu, M. K.; Murakami Iha, N. Y.; Meyer, T. J.; J. Phys. Chem. A 2003, 107, 4092.

125. Polo, A. S.; Itokazu, M. K.; Murakami Iha, N. Y.; J. Photochem. Photobiol., A 2006, 181, 73.

126. Argazzi, R.; Bertolasi, E.; Chiorboli, C.; Bignozzi, C. A.; Itokazu, M. K.; Murakami Iha, N. Y.; Inorg. Chem. 2001, 40, 6885.

127. Patrocinio, A. O. T.; Brennaman, M. K.; Meyer, T. J.; Murakami Iha, N. Y.; J. Phys. Chem. A 2010, 114, 12129.

128. Frin, K. M.; Murakami Iha, N. Y.; J. Braz. Chem. Soc. 2006, 17, 1664

129. Patrocínio, A. O. T.; Murakami Iha, N. Y.; Inorg. Chem. 2008, 47, 10851.

130. Busby, M.; Hartl, F.; Matousek, P.; Towrie, M.; Vlček, A.; Chem. - Eur. J. 2008, 14, 6912.

131. Itokazu, M. K.; Polo, A. S.; de Faria, D. L. A.; Bignozzi, C. A.; Murakami Iha, N. Y.; Inorg. Chim. Acta 2001, 313, 149.

132. Yam, V. W.; Lau, V. C.; Wu, L.; J. Chem. Soc. Dalton Trans. 1998, 1461.

133. Bossert, J.; Daniel, C.; Chem. - Eur. J. 2006, 12, 4835.

134. Kayanuma, M.; Gindensperger, E.; Daniel, C.; Dalton Trans. 2012, 41, 13191.

135. Busby, M.; Matousek, P.; Towrie, M.; Vlček, A.; J. Phys. Chem. A 2005, 13, 3000.

136. Vlček, A.; Busby, M.; Coord. Chem. Rev. 2006, 250, 1755.

137. Frin, K. P. M.; Zanoni, K. P. S.; Murakami Iha, N. Y.; Inorg. Chem. Commun. 2012, 20, 105.

138. Gindensperger, E.; Köppel, H.; Daniel, C.; Chem. Commun. 2010, 46, 8225 .

139. Daniel, C.; Coord. Chem. Rev. 2015, 282-283, 19.

140. Sathish, V.; Babu, E.; Ramdass, A.; Lu, Z.-Z. Z.; Chang, T.-T. T.; Velayudham, M.; Thanasekaran, P.; Lu, K.-L. L.; Li, W.-S. S.; Rajagopal, S.; RSC Adv. 2013, 3, 18557.

141. Zanoni, K. P. S.; Murakami Iha, N. Y.; Dalton Trans. 2017, 46, 9951.

142. Wrighton, M. S.; Morse, D. L.; Pdungsap, L.; J. Am. Chem. Soc. 1975, 97, 2073.

143. Merino, E.; Ribagorda, M.; Beilstein J. Org. Chem. 2012, 8, 1071.

144. Kamiya, Y.; Asanuma, H.; Acc. Chem. Res. 2014, 47, 1663.

145. Kassem, S.; Van Leeuwen, T.; Lubbe, A. S.; Wilson, M. R.; Feringa, B. L.; Leigh, D. A.; Chem. Soc. Rev. 2017, 46, 2592.

146. Bianchi, A.; Delgado-Pinar, E.; García-España, E.; Giorgi, C.; Pina, F.; Coord. Chem. Rev. 2014, 260, 156. 
147. Hampp, N.; Chem. Rev. 2000, 100, 1755.

148. Frin, K. P. M.; Murakami Iha, N. Y.; Inorg. Chim. Acta 2011, 376,531 .

149 Amaral, R. C.; Murakami Iha, N. Y.; Dalton Trans. 2018, 47, 13081.

150. Matos, L. S.; Amaral, R. C.; Murakami Iha, N. Y.; Inorg. Chem. 2018, 57, 9316.

151. Frin, K. P. M.: Propriedades Fotoquímicas de alguns Complexos de Ferro(II) e Rênio(I), PhD thesis, University of São Paulo, São Paulo, Brazil, 2008, available at https://www.teses.usp.br/ teses/disponiveis/46/46134/tde-17052016-143939/pt-br.php, accessed in May 2020.

152. Polo, A. S.: Sistemas Químicos Integrados via Complexos de Rênio(I) e Rutênio(II) na Conversão de Energia, $\mathrm{PhD}$ thesis, University of São Paulo, São Paulo, Brazil, 2007, available at https://www.teses.usp.br/teses/disponiveis/46/46134/tde26042007-112045/pt-br.php, accessed in May 2020.

153. Itokazu, M. K.: Reações Fotoinduzidas em alguns Complexos de Rênio e Desenvolvimento de Dispositivos Moleculares, $\mathrm{PhD}$ thesis, University of São Paulo, São Paulo, Brazil, 2005, available at https://teses.usp.br/teses/disponiveis/46/46134/ tde-28062016-112017/en.php, accessed in May 2020.

154. Murakami Iha, N. Y.; An. Acad. Bras. Cienc. 2000, 72, 67.

155. Nunes, B. N.; Paula, L. F.; Costa, Í. A.; Machado, A. E. H.; Paterno, L. G.; Patrocinio, A. O. T.; J. Photochem. Photobiol., C 2017, 32, 1 .

156. Balzani, V.; Credi, A.; Venturi, M.; ChemSusChem 2008, 1, 26.

157. Ferreira, A.; Kunh, S. S.; Fagnani, K. C.; de Souza, T. A.; Tonezer, C.; dos Santos, G. R.; Coimbra-Araújo, C. H.; Renewable Sustainable Energy Rev. 2018, 81, 181.

158. Saxena, V.; Aswal, D. K.; Semicond. Sci. Technol. 2015, 30, 064005 .

159. Ragoussi, M.-E.; Torres, T.; Chem. Commun. 2015, 51, 3957.

160. Sugathan, V.; John, E.; Sudhakar, K.; Renewable Sustainable Energy Rev. 2015, 52, 54.

161. Ye, M.; Wen, X.; Wang, M.; Iocozzia, J.; Zhang, N.; Lin, C.; Lin, Z.; Mater. Today 2015, 18, 155.

162. Grätzel, M.; J. Photochem. Photobiol., C 2003, 4, 145.

163. Pazoki, M.; Cappel, U. B.; Johansson, E. M. J.; Hagfeldt, A.; Boschloo, G.; Energy Environ. Sci. 2017, 10, 672.

164. Sharifi, N.; Tajabadi, F.; Taghavinia, N.; ChemPhysChem 2014, 15,3902 .

165. Yu, Z.; Vlachopoulos, N.; Gorlov, M.; Kloo, L.; Dalton Trans. 2011, 40, 10289.

166. Kakiage, K.; Aoyama, Y.; Yano, T.; Oya, K.; Fujisawa, J. I.; Hanaya, M.; Chem. Commun. 2015, 51, 15894.

167. Lee, C. P.; Li, C. T.; Ho, K. C.; Mater. Today 2017, $20,267$.

168. Baxter, J. B.; J. Vac. Sci. Technol., A 2012, 30, 020801.

169. Fakharuddin, A.; Jose, R.; Brown, T. M.; Fabregat-Santiago, F.; Bisquert, J.; Energy Environ. Sci. 2014, 7, 3952.
170. Murukami Iha, N. Y.; Bignozzi, C. A.; Garcia, C. G.; Argazzi, R.; BR pat. PI 0104993-3, 2001.

171. Murakami Iha, N. Y.; Garcia, C. G.; Argazi, R.; Bignozzi, C. A.; BR pat. PI0101629-6, 2001.

172. Murakami Iha, N. Y.; Garcia, C. G.; Polo, A. S.; BR pat. PI0203334-1, 2002.

173. Murakami Iha, N. Y.; Garcia, C. G.; Polo, A. S.; BR pat. PI0203234-1, 2002.

174. Murakami Iha, N. Y.; Polo, A. S.; Garcia, C. G.; BR pat. PI0701973-4, 2007.

175. Murakami Iha, N. Y.; Patrocínio, A. O. T.; Paterno, L. G.; BR pat. PIO802589-4, 2008

176. Muhammad, N.; Zanoni, K. P. S.; Murakami Iha, N. Y.; Ahmed, S.; ChemistrySelect 2018, 3, 10475.

177. Muhammad, N.; Zanoni, K. P. S.; Coppo, R. L.; Ahmed, S.; Murukami Iha, N. Y.; J. Photochem. Photobiol., A 2017, 332, 432.

178. Garcia, C. G.; Kleverlaan, C. J.; Bignozzi, C. A.; Murakami Iha, N. Y.; J. Photochem. Photobiol., A 2002, 147, 143.

179. Garcia, C. G.; Nakano, A. K.; Kleverlaan, C. J.; Murakami Iha, N. Y.; J. Photochem. Photobiol., A 2002, 151, 165.

180. Qin, Y.; Peng, Q.; Int. J. Photoenergy 2012, 2012, 291579.

181. Pashaei, B.; Shahroosvand, H.; Graetzel, M.; Nazeeruddin, M. K.; Chem. Rev. 2016, 116, 9485.

182. Polo, A. S.; Itokazu, M. K.; Murakami Iha, N. Y.; Coord. Chem. Rev. 2004, 248, 1343.

183. Garcia, C. G.; Murakami Iha, N. Y.; Argazzi, R.; Bignozzi, C. A.; J. Photochem. Photobiol., A 1998, 115, 239.

184. Garcia, C. G.; Murakami Iha, N. Y.; Int. J. Photoenergy 2001, 3,130 .

185. Garcia, C. G.; Murakami Iha, N. Y.; Argazzi, R.; Bignozzi, C. A.; J. Braz. Chem. Soc. 1998, 9, 13.

186. Silva, M. D. S. P.; Diógenes, I. C. N.; de Carvalho, I. M. M.; Zanoni, K. P. S.; Amaral, R. C.; Murakami Iha, N. Y.; J. Photochem. Photobiol., A 2016, 314, 75.

187. Chaurasia, S.; Lin, J. T.; Chem. Rec. 2016, 16, 1311.

188. Nazeeruddin, M. K.; Baranoff, E.; Grätzel, M.; Sol. Energy 2011, 85, 1172.

189. Bignozzi, C. A.; Argazzi, R.; Boaretto, R.; Busatto, E.; Carli, S.; Ronconi, F.; Caramori, S.; Coord. Chem. Rev. 2013, 257, 1472.

190. Shalini, S.; Prabhu, R. B.; Prasanna, S.; Mallick, T. K.; Senthilarasu, S.; Renewable Sustainable Energy Rev. 2015, 51, 1306.

191. Calogero, G.; Bartolotta, A.; Di Marco, G.; Di Carlo, A.; Bonaccorso, F.; Chem. Soc. Rev. 2015, 44, 3244.

192. Ludin, N. A.; Mahmoud, A. M. A.-A.; Mohamad, A. B.; Kadhum, A. A. H.; Sopian, K.; Karim, N. S. A.; Renewable Sustainable Energy Rev. 2014, 31, 386.

193. Hug, H.; Bader, M.; Mair, P.; Glatzel, T.; Appl. Energy 2014, $115,216$. 
194. Al-Alwani, M. A. M.; Mohamad, A. B.; Ludin, N. A.; Kadhum, A. A. H.; Sopian, K.; Renewable Sustainable Energy Rev. 2016, 65, 183.

195. Richhariya, G.; Kumar, A.; Tekasakul, P.; Gupta, B.; Renewable Sustainable Energy Rev. 2017, 69, 705.

196. Zhou, H.; Wu, L.; Gao, Y.; Ma, T.; J. Photochem. Photobiol., A 2011, 219, 188.

197. Iqbal, M. Z.; Ali, S. R.; Khan, S.; Sol. Energy 2019, 181, 490.

198. Patrocínio, A. O. T.; Mizoguchi, S. K.; Paterno, L. G.; Garcia, C. G.; Murakami Iha, N. Y.; Synth. Met. 2009, 159, 2342.

199. Patrocínio, A. O. T.; Murakami Iha, N. Y.; Quim. Nova 2010, 33,574

200. Garcia, C. G.; Polo, A. S.; Murakami Iha, N. Y.; J. Photochem. Photobiol., A 2003, 160, 87.

201. Polo, A. S.; Murakami Iha, N. Y.; Sol. Energy Mater. Sol. Cells 2006, 90, 1936.

202. Amaral, R. C.; Barbosa, D. R. M.; Zanoni, K. P. S.; Murakami Iha, N. Y.; J. Photochem. Photobiol., A 2017, 346, 144.

203. Murakami Iha, N. Y.; Garcia, C. G.; Bignozzi, C. A. In Handbook of Photochemistry and Photobiology; American Scientific Publishers: Stevenson Ranch, California, USA, 2003, p. 49-82.

204. Calogero, G.; Yum, J.-H. H.; Sinopoli, A.; Di Marco, G.; Grätzel, M.; Nazeeruddin, M. K.; Sol. Energy 2012, 86, 1563.

205. Grätzel, M.; Nature 2001, 414, 338.

206. House, R. L.; Murakami Iha, N. Y.; Coppo, R. L.; Alibabaei, L.; Sherman, B. D.; Kang, P.; Brennaman, M. K.; Hoertz, P. G.; Meyer, T. J.; J. Photochem. Photobiol., C 2015, 25, 32.

207. Meyer, T. J.; Sheridan, M. V.; Sherman, B. D.; Chem. Soc. Rev. 2017, 46, 6148 .

208. Brennaman, M. K.; Dillon, R. J.; Alibabaei, L.; Gish, M. K.; Dares, C. J.; Ashford, D. L.; House, R. L.; Meyer, G. J.; Papanikolas, J. M.; Meyer, T. J.; J. Am. Chem. Soc. 2016, 138, 13085.

209. Song, W.; Chen, Z.; Glasson, C. R. K.; Hanson, K.; Luo, H.; Norris, M. R.; Ashford, D. L.; Concepcion, J. J.; Brennaman, M. K.; Meyer, T. J.; ChemPhysChem 2012, 13, 2882.

210. Gibson, E. A.; Chem. Soc. Rev. 2017, 46, 6194.

211. Dalle, K. E.; Warnan, J.; Leung, J. J.; Reuillard, B.; Karmel, I. S.; Reisner, E.; Chem. Rev. 2019, 119, 2752.

212. Song, W.; Chen, Z.; Brennaman, M. K.; Concepcion, J. J.; Patrocinio, A. O. T.; Murakami Iha, N. Y.; Meyer, T. J.; Pure Appl. Chem. 2011, 83, 749.

213. Concepcion, J. J.; Jurss, J. W.; Brennaman, M. K.; Hoertz, P. G.; Patrocinio, A. O. T.; Murakami Iha, N. Y.; Templeton, J. L.; Meyer, T. J.; Acc. Chem. Res. 2009, 42, 1954.

214. Brennaman, M. K.; Patrocinio, A. O. T.; Song, W.; Jurss, J. W.; Concepcion, J. J.; Hoertz, P. G.; Traub, M. C.; Murakami Iha, N. Y.; Meyer, T. J.; ChemSusChem 2011, 4, 216.

215. Sheridan, M. V.; Sherman, B. D.; Coppo, R. L.; Wang, D.; Marquard, S. L.; Wee, K.-R.; Murakami Iha, N. Y.; Meyer, T. J.; ACS Energy Lett. 2016, 1, 231.
216. O’Regan, B.; Grätzel, M.; Nature 1991, 353, 737.

217. Hagfeldt, A.; Boschloo, G.; Sun, L.; Kloo, L.; Pettersson, H.; Chem. Rev. 2010, 110, 6595.

218. Nakata, K.; Fujishima, A.; J. Photochem. Photobiol., C 2012 , 13, 169.

219. Yang, W.-G.; Wan, F.-R.; Chen, Q.-W.; Li, J.-J.; Xu, D.-S.; J. Mater. Chem. 2010, 20, 2870.

220. Ye, M.; Zheng, D.; Wang, M.; Chen, C.; Liao, W.; Lin, C.; Lin, Z.; ACS Appl. Mater. Interfaces 2014, 6, 2893.

221. Sun, X.; Liu, Y.; Tai, Q.; Chen, B.; Peng, T.; Huang, N.; Xu, S.; Peng, T.; Zhao, X.; J. Phys. Chem. C 2012, 116, 11859.

222. Raj, C. C.; Prasanth, R.; J. Power Sources 2016, 317, 120.

223. Concina, I.; Vomiero, A.; Small 2015, 11, 1744.

224. Ameri, M.; Samavat, F.; Mohajerani, E.; Fathollahi, M.-R.; J. Phys. D: Appl. Phys. 2016, 49, 225601.

225. Sudhagar, P.; Asokan, K.; Jung, J. H.; Lee, Y. G.; Park, S.; Kang, Y. S.; Nanoscale Res. Lett. 2011, 6, 30.

226. Xia, J.; Masaki, N.; Jiang, K.; Yanagida, S.; J. Phys. Chem. B 2006, 110, 25222.

227. Sangiorgi, A.; Bendoni, R.; Sangiorgi, N.; Sanson, A.; Ballarin, B.; Ceram. Int. 2014, 40, 10727.

228. Hart, J. N.; Menzies, D.; Cheng, Y. B.; Simon, G. P.; Spiccia, L.; C. R. Chim. 2006, 9, 622.

229. Grosso, D.; J. Mater. Chem. 2011, 21, 17033.

230. Al-Juaid, F.; Merazga, A.; Abdel-Wahab, F.; Al-Amoudi, M.; World J. Condens. Matter Phys. 2012, 02, 192.

231. Kim, D. H.; Woodroof, M.; Lee, K.; Parsons, G. N.; ChemSusChem 2013, 6, 1014.

232. Niu, W.; Li, X.; Karuturi, S. K.; Fam, D. W.; Fan, H.; Shrestha, S.; Wong, L. H.; Tok, A. I. Y.; Nanotechnology 2015, 26, 064001.

233. Agrios, A. G.; Cesar, I.; Comte, P.; Nazeeruddin, M. K.; Grätzel, M.; Chem. Mater. 2006, 18, 5395.

234. Mártire, A. P.; Segovia, G. M.; Azzaroni, O.; Rafti, M.; Marmisollé, W.; Mol. Syst. Des. Eng. 2019, 4, 893.

235. Gross, M. A.; Sales, M. J. A.; Soler, M. A. G.; Pereira-da-Silva, M. A.; da Silva, M. F. P.; Paterno, L. G.; RSCAdv. 2014, 4, 17917.

236. Akiba, U.; Minaki, D.; Anzai, J. I.; Polymers 2017, 9 , 1.

237. Zeng, J.; Matsusaki, M.; Polym. Chem. 2019, 10, 2960.

238. Paterno, L. G.; Soler, M. A. G.; JOM 2013, 65, 709.

239. Patrocínio, A. O. T.; Paterno, L. G.; Murakami Iha, N. Y.; J. Photochem. Photobiol., A 2009, 205, 23.

240. Patrocinio, A. O. T. T.; Paterno, L. G.; Iha, N. Y. M.; Murakami Iha, N. Y.; J. Phys. Chem., C 2010, 114, 17954.

241. Paula, L. F.; Amaral, R. C.; Murakami Iha, N. Y.; Paniago, R. M.; Machado, E. H.; Patrocinio, A. O. T.; RSC Adv. 2014, 4, 10310.

242. Matos, L. S.; Amaral, R. C.; Murakami Iha, N.Y.; ChemistrySelect 2019, 4, 265.

243. Zanoni, K. P. S.; Amaral, R. C.; Murakami Iha, N. Y.; ACS Appl. Mater. Interfaces 2014, 6, 10421. 
244. Zanoni, K. P. S.; Amaral, R. C.; Murakami Iha, N. Y.; Abreu, F. D.; de Carvalho, I. M. M.; Spectrochim. Acta, Part A 2018, 198, 331.

245. Patrocinio, A. O. T.; El-Bachá, A. S.; Paniago, E. B.; Paniago, R. M.; Murakami Iha, N. Y.; Int. J. Photoenergy 2012, 2012, 1.

246. Coppo, R. L.; Farnum, B. H.; Sherman, B. D.; Murakami Iha, N. Y.; Meyer, T. J.; Sustainable Energy Fuels 2017, 1, 112.

247. Murakami Iha, N. Y.; Garcia, C. G.; Registro de Marca - Dye- cell, dirma 823895718, 2001, available at http://revistas.inpi. gov.br/pdf/marcas1893.pdf, accessed in May 2020.

248. Garcia, C. G.; Murakumi Iha, N. Y.; Int. J. Photoenergy 2001, $3,137$.

Submitted: February 2, 2020

Published online: May 20, 2020 